Maria Laura Viveiros de Castro Cavalcanti'

Valter Sinder"

Giselle Carino Lage ${ }^{\prime \prime \prime}$

\title{
VICTOR TURNER E A ANTROPOLOGIA NO BRASIL. DUAS VISÕES. ENTREVISTAS COM ROBERTO DAMATTA E YVONNE MAGGIE'
}

Roberto DaMatta, atualmente professor titular da Pontifícia Universidade Católica do Rio de Janeiro (PUC-Rio), é autor de vasta e renomada obra. Seus livros mais recentes - como Fé em Deus e pé na tábua: ou como e porque o trânsito enlouquece no Brasil (2010), ou A bola corre mais que os homens (2006) - bem expressam o sucesso desse talentoso mestre na arte antropológica do estranhamento e da relativização. Nos anos I970, em especial, seu livro Carnavais, malandros e heróis. Por uma sociologia do dilema brasileiro (I979) trouxe a cultura e o estudo dos rituais - e com isso a perspectiva antropológica como um todo-, para a ordem do dia na compreensão dos grandes e pequenos temas da sociedade brasileira. No centro dessa potente renovação estavam as teorias antropológicas do ritual e a estreita interlocução de Roberto DaMatta com Victor Turner. Sua entrevista nos traz o contexto ainda pouco conhecido desse fecundo encontro, seu impacto e desdobramentos na formação de DaMatta, cuja obra, por sua vez, marcaria a antropologia e as ciências sociais brasileiras como um todo.

Yvonne Maggie, professora titular do Instituto de Filosofia e Ciências Sociais da Universidade Federal do Rio de Janeiro (IFCS-UFRJ), especializou-se no estudo das religiões afro-brasileiras, dedicando-se mais recentemente também aos problemas do racismo brasileiro e à antropologia da educação. Seus livros Guerra de Orixá: um estudo de ritual e conflito (1975) e Medo do feitiço. Relações entre magia e poder no Brasil (I992) revigoraram os estudos afro-brasileiros no país. Em especial, Guerra de Orixá, sua dissertação de mestrado orientada por 
Roberto DaMatta, destaca-se pelo diálogo direto com Victor Turner. Por meio do uso inovador do conceito de drama social no estudo de um terreiro de umbanda, ela revelou a dinâmica da cisão como forma da produção de novos terreiros nessa religião. Em sua entrevista, Maggie nos fala dessa pesquisa que marca o momento inicial da recepção da obra de Victor Turner no Brasil e que abriu novos caminhos na antropologia urbana e na antropologia da religião.

Com sua obra original e multifacetada, Victor Turner (I920-I983), o autor enfocado nestas entrevistas, destacou-se no cenário da antropologia da segunda metade do século XX. Seu livro inaugural, Schism and continuity in an African society. A study of Ndembu village life (I957) consagrou-o entre os africanistas e revigorou a perspectiva estrutural funcionalista com o conceito de drama social, que sintetiza de modo criativo sua visão da vida social como um processo permeado de conflitos, rituais e simbolização. Seus estudos subsequentes sobre simbolismo e rituais Ndembu são sempre saudados pela crítica não só por sua riqueza etnográfica como pela conjugação da perspectiva sociológica com exímias análises simbólicas. Floresta dos símbolos, seu livro de 1967, traduzido em 2005 pela EdUFF, bem atesta a fecundidade de suas ideias. Prolixo e heterodoxo, Victor Turner logo iluminaria também, com a elaboração do par conceitual estrutura/communitas, processos e experiências de sua própria cultura - peregrinações, rebeliões, movimento hippie, entre outros. Essa nova fase emerge com nitidez em O processo ritual, de I969, traduzido em I 974 pela Editora Vozes em coleção dirigida, juntamente com o professor Luis de Castro Faria, pelo então jovem professor Roberto DaMatta. Dramas, campos e metáforas, de i974, traduzido em 2008 pela EdUFF, inscreve-se nessa mesma fase. Já no final de sua vida, Victor Turner rumou com sua bagagem antropológica na direção dos estudos e atividades teatrais, propondo as antropologias da performance e da experiência que tanto interessam, nos dias atuais, os estudiosos da cultura de modo geral.

\section{ROBERTO DAMATTA}

Maria Laura Viveiros de Castro Cavalcanti. O foco da nossa conversa é Victor Turner e o seu diálogo com ele é intenso. Relemos suas entrevistas, a "Conversa com o autor", na Reunião da Associação Brasileira de Antropologia (ABA) em Goiás, e sua introdução à edição brasileira de Floresta dos símbolos. ${ }^{2}$ Em uma dessas ocasiões, você fala, com relação a Victor Turner, que não se trata mesmo de uma influência, mas de um encontro espiritual, de uma amizade, e que você o vê como um companheiro de aventura intelectual. Então, queríamos conversar sobre sua visão da obra de Turner e a relação disto com a sua própria obra.

Roberto DaMatta. Eu ouvi falar do Victor Turner pela primeira vez na minha vida em I963, na Universidade de Harvard, em Cambridge, Massachusetts, em um seminário de um africanista que se chamava Thomas Beidelman, que fez 
o doutorado com Rodney Needham, do mesmo modo que o meu professor, que era o David Maybury-Lewis. Tom e David eram colegas, tinham transitado em Oxford juntos. Mas o Tom estudou uma sociedade da África Oriental, e tinha muitas ligações com Evans-Pritchard, que era o herói cultural dele.

M.L.V.C.C. Ele tem vários artigos sobre temas do Evans-Pritchard, não é? R.M. Vários artigos. Ele tinha uma conexão muito forte com o Rodney Needham. Esse não era nem um herói cultural, era uma espécie de semideus, um demiurgo. Tom tinha uma relação apaixonada com o Needham, e era um homem muito complexo. Fui fazer um seminário com ele em I963, junto com o Terry Turner. Foi quando ouvi falar de toda a problemática das sociedades africanas. Turner era também africanista, trabalhou na África Central, e o Tom passou para nós um artigo mimeografado - naquela época não havia os recursos de hoje - do Victor Turner, que era um embrião das ideias sobre communitas, sobre rituais etc. ${ }^{3}$ Ele passou, inclusive pedindo para não citar. E eu fiquei muito interessado porque ele era um professor muito dedicado aos alunos, ele saía para jantar, era um sujeito interessante. E ele tinha coisas curiosas: por exemplo, eu tinha uma salinha no mesmo prédio em que ele trabalhava, na Bow Street, em Cambridge, I 2 Bow Street, Departamento de Relações Sociais. Era uma salinha para dois alunos, eu tinha uma mesa, e ficava trabalhando. Estava trabalhando com o meu material Apinajé, estudando, lendo muito Lévi-Strauss. Foi na época que eu conheci o Pierre Maranda, que fazia outro seminário junto comigo. O Maranda me estimulou muito. E eu me lembro de o Tom uma vez bater na porta, com a revista Man, que hoje se chama The Journal of the Royal Anthropological Institute. Ele dizia: "Você leu esse artigo do Lévi-Strauss sobre o barbeiro e o urso?" ("The bear and the barber", foi uma conferência que ele fez em Oxford e tinha sido publicada.) - "Você leu isso aqui?". Eu disse: - "Não". - "Mas como você não leu? O David não diz para os alunos dele o que eles têm que ler!?" Isto porque era assim que ele tinha sido disciplinado lá em Oxford. Rodney Needham dizia: "este aqui vocês não podem ler, não leiam este". Inclusive Needham dizia em um artigo "ainda tem gente que pensa que tem que ler Meyer Fortes”! Imagina o exagero. E a agressão. Muito agressivo. E o Meyer Fortes é um escritor admirável.

Então, o Tom Beidelman chegou para mim com esse artigo... Foi ele também, curiosamente, quem anunciou o assassinato do John Kennedy em novembro de i963. Eu estava lá, foi o meu primeiro inverno em Cambridge. Fiquei admirado: um dia eu olhei para o relógio às quatro horas da tarde e estava tudo escuro, pensei: - "Não é possível, estou estudando tanto e perdi a hora, são sete horas da noite!" Eram quatro e meia da tarde, aquele negócio escuro, cinzento, o inverno no Norte.

O Tom me levou ao Victor Turner e eu fiquei muito interessado no ritual como uma dimensão social, porque no fundo da minha cabeça tinha o proble- 
ma brasileiro. Eram os anos de I963 para I964 e eu fui para Harvard 4 absolutamente esquerdista, tinha até recebido um convite para entrar no Partido Comunista, em Niterói. Não entrei, mas viajei absolutamente esquerdista. Naquela época era difícil fazer um telefonema, não tinha computador, notícia de jornal, não tinha nada. Carta chegava em quinze dias. Eu estava lá, e nós ficamos sabendo do golpe militar, que eu não esperava. A primeira notícia do golpe militar que eu tive foi a de que tínhamos feito a nossa revolução no país, e não era bem isso...

Valter Sinder. Era o contrário! (risos)

R.M. Eu provavelmente escapei de algumas coisas ruins, certamente ruins, porque eu era professor da Universidade Federal Fluminense. Então, na minha cabeça, era preciso estudar melhor o Brasil, era preciso entender melhor o Brasil. E essa problemática se superimpôs àquilo tudo que eu estava lendo e me dedicando a fazer, que era a pesquisa com os índios.

Então, o que o Victor Turner abriu? Primeiro, ele abriu a possibilidade para estudar rituais, junto com o Beidelman e com o estruturalismo lévistraussiano - que os ingleses acompanhavam de maneira empírica, com viés pragmático e não filosófico, porque eles queriam testar aquelas ideias. Eles não aceitavam aquela parte especulativa lévistraussiana, porque ele também não sabia para onde ele estava indo, ele próprio estava inventando tudo aquilo, não é mesmo? O grupo indígena que eu estudei, tanto os Gaviões quanto os Apinajés, mas sobretudo os Apinajés, tinham muito ritual. O [Julio Cesar] Melatti estava estudando os Krahó e o Terence Turner tinha estudado os índios Kayapó, tinha passado uma temporada com os Kayapó e estava trabalhando na tese dele. Todos esses grupos tinham uma vida social muito ritualizada.

M.L.V.C.C. O Melatti escreveu Rituais Timbira.

R.M. Um livro maravilhoso, um dos melhores livros escritos sobre rituais Timbira. Nós fomos juntos para os Gaviões, em I96I. Ficamos de agosto a novembro entre os Gaviões, nós dois. Sem nenhuma experiência porque era a antropologia brasileira em I96r! O Roberto Cardoso [de Oliveira] tinha estudado os índios Terena, lá tinha Posto indígena e ele ficou hospedado na casa do encarregado do Posto. Eu, quando cheguei nos Gaviões, me perguntei: - "Quem é que vai cozinhar?" O problema da empregada doméstica! - "Quem é que vai cozinhar? Como é que lava a roupa? Remédio, como é que você faz? Tem que ter uma farmácia!" Coisas que os ingleses aprenderam com os missionários, com os administradores coloniais com os quais eles se comunicavam e alguns tinham escrito artigos importantes sobre as tribos que os antropólogos estudaram. E eles trabalhavam com sociedades que tinham centenas de milhares de pessoas. Como foi o caso de Evans-Pritchard com os Nuer, que tinham sido bombardeados pela RAF [Royal Air Force]! O Meyer Fortes trabalhou com os Tallensi; ele 
e sua esposa foram o primeiro casal branco a visitar os Tallensi no começo dos anos I930, e eram milhares de Tallensi em Gana, nas montanhas de Gana!

Então, esses caras tinham assistentes de pesquisa. Quando a gente conversava nos coquetéis, quando o Maybury-Lewis conversava com Tom Beidelman, com Douglas Oliver, com os antropólogos que tinham trabalhado na Polinésia, na África - sobretudo com os africanistas -, o contraste entre as condições do trabalho de campo era enorme. Na verdade, ninguém tinha trabalhado com os índios americanos. Isso é um ponto importante que eu descobri agora. Tinha um livro sobre o sistema legal dos Cheyenne, mas ninguém tinha escrito ainda. Eu tinha lido o [Robert] Lowie. A autobiografia do Lowie é muito interessante, há pouco tempo eu reli, e ele - como nós - estava procurando índio. Ele era aluno do Franz Boas e foi estudar as populações indígenas americanas. E onde é que estavam os índios? Todos dizimados! Era a mesma minha experiência: "Eu vou procurar índio. Eu quero uma sociedade indígena funcionando e sem traumas".

Em agosto de ig6r chegamos na aldeia dos índios Gaviões, Melatti e eu, com um encarregado que nos levou - um dia e meio a pé, e uma noite dormida no meio do mato. Chegamos lá e encontramos 2I índios: um velho, duas crianças, e um monte de índios que só faziam chorar e dizer que estava tudo acabando. Havia um grupo de mais 20 nativos que estava caçando, tinha o tal capitão que estava caçando e chegou depois. Relendo meus diários agora, vejo que era um terror, porque não tinha o professor, o informante! E havia o nosso abuso! De repente, imaginem vocês, chegarem na sua casa dois marcianos: "Quem é sua mãe? Ela mora com você? A gente come aqui?" (risos). E chegamos com objetos valiosos - a única coisa certa que fizemos, graças ao Frei Gil, um dominicano que tinha visitado os Gaviões e nos aconselhou. Levamos duas latas de goiabada, biscoitos, e foi o que nos salvou no primeiro mês, no segundo mês.

Então, a conexão com a obra do Turner foi a partir dessa ideia do símbolo, do ritual, de uma maneira muito mais, digamos assim, precisa, concreta... No Lévi-Strauss é uma álgebra! Importantíssimo, mas eu estou falando de um Lévi-Strauss que não existia ainda. O Lévi-Strauss das Mithologiques vem depois. Porque em 1963, o Lévi-Strauss de quem eu estou falando é o Lévi-Strauss de Antropologia estrutural, de alguns artigos avulsos publicados na American Anthropology, como o artigo "O feiticeiro e sua magia". É o Lévi-Strauss, sobretudo, de Le totemisme aujourd'hui e de $O$ pensamento selvagem, que eu levei para o campo. Este livro, eu levei para o campo! Discuti, li e levei para o campo. Era uma espécie de breviário. Quando eu visitei o Lévi-Strauss pela primeira vez, levei este livro para ele autografar. Não é nem em francês, é um livro publicado no México, está guardado lá em casa e ele fez uma dedicatória assim: "a este livro, duplamente sagrado - porque está assinado por mim (risos...) e, ao mesmo tempo, foi batizado no 'terreno', no campo". Sem dizer "Cordialmente, ou com 
um abraço cordial"... Ele era um aristocrata, não é? O avô era rabino, nunca falou da vida íntima dele, ninguém sabe nada, era discretíssimo. Era o estilo dele. Então ele assinou isso para mim.

Mas, com o Victor Turner, a abertura foi essa... Antes de eu voltar para o Brasil é que a obra do Vic ficou mais importante ainda, porque visitei o Vic na Universidade de Cornell, em Ithaca, acho que em novembro de $1963 .{ }^{5}$

M.L.V.C.C. É interessante, são encontros imprevistos. Porque você está vindo de um deslocamento da etnologia brasileira para uma oportunidade de prosseguir a formação na Universidade de Harvard, num centro intelectual mundial. E o Turner, por sua vez, estava fugindo um pouco de uma certa rigidez do estrutural-funcionalismo mais stricto sensu, não?

R.M. Tinha mais coisa do que isso. Na sala da casa do Victor Turner, em Chicago - um apartamento que não sei se era dele ou da universidade e era alugado pelos professores; eram uns apartamentos funcionais, muito bem desenhados, modernos, tinha espaço, ele tinha dois filhos, dois rapazes. E, na sala dele - que era uma sala decorada de uma maneira super modesta, tinha uma vitrolinha pequenininha, não tinha televisão - tinha um retrato do professor dele, do Max Gluckman, que eu conheci também depois. Fizemos um seminário com Max Gluckman, em I974, foi entre 24 de agosto e I de setembro, no castelo Burg Warttenstein, na Áustria, sob o patrocínio da Wenner-Gren Foundation for Anthropological Research. Então, o Gluckman foi fundador do departamento de Manchester em que o Turner estudou, foi o estudioso que introduziu na antropologia o conflito como foco e como algo funcional, e também a ideia de campo (social field), algo famoso no Brasil como invenção do Bourdieu. O Turner vinha da literatura, a mãe dele era atriz de teatro, e ele - corria o folclore - não sabia quem era o pai dele. Você imagina! Em I920, uma atriz de teatro, mesmo na Inglaterra...

M.L.V.C.C. Eu sabia que ele tinha sido criado pelos avós.

R.M.: Quando chegou no final da vida dele - porque é sempre no final que você volta para o início, isso é certo, quase certo, no final você vai buscar o projeto inicial, projeto e impulsos iniciais - o que Turner foi fazer? Com quem ele se associou, para ciúme de todos os discípulos? Com Richard Schechner, que era diretor de teatro em Nova York. Eu assisti a uma conferência inimaginável: nos anos I980, participei de uma conferência em Nova York sobre teatro\&ritual, produzida por Victor Turner e Schechner. Então, lá estávamos, o meu querido John McAloon, que escreveu sobre jogos olímpicos, escreveu uma biografia maravilhosa sobre o Barão de Coubertin, e hoje é membro do Comitê Olímpico Americano e foi atleta olímpico. Ele e eu ficamos com ciúmes do Vic. O Vic, em vez de se ligar com a gente, se liga com um cara de teatro!!? O Schechner foi numa reunião, a segunda reunião que eu fui na Wenner-Gren Foundation, no 
castelo, em I978, se não me engano. O Vic o levou e ele deu uma aula de preparação de atores para os antropólogos. Eu e o australiano Bruce Kapferer, que hoje é professor da Universidade de Bergen, na Noruega, nos recusamos a participar porque ficamos com medo, tinha que fazer técnicas de respirar para poder falar bem (risos), nós achamos aquilo tudo estranhíssimo! O Schechner, no meio da conferência, foi embora. Mas ele escreveu um livro sobre ritual e performance junto com Turner, que é um livro muito interessante. Então, tinha essa conexão. O Turner sai de Manchester, sai da Inglaterra porque não tinha lugar para trabalhar na Inglaterra. Primeiro ponto. Mas, segundo ponto, porque em Manchester ele não podia ficar! Eu assisti a uma conferência em que ele estava presente junto com o Gluckman, e tinha uma competição de bala de prata do Gluckman em relação a ele, e ele não falava nada. Ele não era um cara de brigar, era um cara "viva e deixe viver". Por isso que ele veio para o Brasil; foi o único que veio para o Brasil... Não só veio como ficou aqui um mês, entre fevereiro e março de i979. Naquela época, imaginem vocês, o Rodney Needham não deixava você tirar uma fotografia dele, era um homem-índio!: "Não é assim que eu quero ficar para a posterity. Only books! Not pictures!" (risos). Ele não dava entrevista em televisão, nunca deu entrevista para jornalista nenhum. Porque a posteridade para ele eram os livros, ou os livros ficam ou eu não fico. Nessa reunião sobre rituais que eu estava quando era jovem...

V.S. Na primeira?

R.M. Na primeira, em I974, da qual resultou o livro Secular rituals, editado por Sally F. Moore e Barbara Myerhoff, no qual eu contribui com o cap. XIII, "Constraint and license: A preliminary study of two Brazilian national rituals". O Gluckman era um coronel do exército reformado da guerra, tinha um porte militar. Mas havia os momentos de passeios, essa coisa dos ingleses: "Let's go for a walk!" (risos). O Gluckman tinha umas coisas muito interessantes, tinha esse lado...

Voltando para a casa do Vic e da Edith Turner (sua esposa incrivelmente fiel e que o amava profundamente) em Chicago, havia na parede um retrato: “Quem é este?". Eu respondi: - "Max Gluckman". Era um retrato de rosto. Ele disse: - "Olha só, repara! Olha como o lado direito é completamente diferente do lado esquerdo!" Ele tapava um dos lados com a mão e deu uma aula. Ele tinha dois retratos! Essas coisas são muito interessantes e ajudam a entender a cabeça desse homem, do Vic. Ao lado havia uma gravura do William Blake, o poeta, milenarista, genial e louco, que desenhava, e tinha essa preocupação com deus, com os demônios e tal, um grande poeta. De um lado da sala, o Vic tinha uma gravura de um anjo, feita por esse poeta e, do outro lado, Max Gluckman, o seu professor de uma antropologia voltada para o conflito e para o campo político! E com esse detalhe, que um lado do rosto era o lado mau, e o outro lado era o lado bom. O que é um truísmo, não é? Todos nós temos uma 
mão esquerda e uma mão direita. Um pé que chuta para fora e um pé que chuta para dentro. Mas ele não falava nada do Gluckman. O Gluckman era - corria o folclore de Manchester - um homem que, nos seminários das sextas-feiras, em que os alunos de doutorado voltavam do campo com os seus dados, fazia com que alguns saíssem chorando do seminário. E o Turner, que tinha esse lado de ator, imitava! Naqueles seminários em Oxford, Cambridge e em Manchester, com os ingleses, porque ele era escocês, esse dado é importante...

V.S. Ele era católico, não é?

R.M. Católico. Convertido, como o Evans-Pritchard, ao catolicismo. O catolicismo dele é um outro folclore interessante.

Mas voltando: quem fazia esses seminários? Clyde Mitchell, Peter Worsley, Elizabeth Colson, Ian Lewis, alguns caras que tinham estudado na Nova Guiné e África do Sul coisas como destribalização e urbanização ou favelização de ex-membros de aldeias nativas nas cidades segregadas da África do Sul. Era um grupo interessado... O Gluckman tinha trabalhado no Instituto Rhodes-Livingstone, na África, do qual foi um dos diretores, e dali foi para Manchester. Em Manchester, ele fundou o departamento de antropologia. Imaginem vocês: uma universidade inglesa abrir um departamento de antropologia para um judeu sul-africano (como o Meyer Fortes, de quem era muito amigo) e entregar a ele! Nessas caminhadas com ele, emergia o seu lado, digamos assim, "fraterno", o qual era estimulado pela minha marginalidade como brasileiro, uma identidade totalmente desconhecida para aqueles professores que sabiam o que era um Ashanti, um Nuer ou um Beba, mas não tinham a menor ideia do que seria um "brasileiro"... Uma vez eu estava andando com ele (Gluckman) e ele recitou uma poesia, uma estrofe de um poeta inglês que não me lembro porque eu não sou versado em poesia inglesa; ou irlandês talvez. Ele recitou, e olhou para o Turner e, com um olhar nostálgico, falou: “o E-P. adorava esta poesia!” Por quê? Porque a vida desses caras era a antropologia. Lá em Oxford, esse seminário do Radcliffe-Brown - diferentemente de Londres, em que o Malinowski dominava, o império do Malinowski era Londres, uma grande cidade, como Paris. Oxford, como Cambridge eram aldeias ou conventos. Então lá em Oxford, os alunos iam para o seminário, mas entre um seminário e outro...

M.L.V.C.C. Acontece um monte de outras coisas, que ninguém controla.

R.M. Tem teatro, cinema, tem o museu para ver não sei o quê, tem vida boêmia, não é? O Lévi-Strauss disse isso uma vez: "eu nunca aceitei o contrato que Harvard me ofereceu" - o contrato já estava escrito, era só ele assinar - "porque eu sou um boêmio, falei para o próprio Parsons, eu sou um boêmio, eu quero ficar em Paris". Obviamente, a boemia parisiense é uma maneira de dizer "não quero ir", mas "eu não vou abandonar uma cidade como Paris". Tinha essa coisa francesa, parisiense dele. Mas no caso do Turner, desses caras, vários me 
contaram, era um grupo pequeno de Io, I2 pessoas, na Inglaterra eles se chamavam - o Maybury-Lewis falou uma vez para mim, os "seven samurais". Havia os sete samurais, eram os professores titulares, catedráticos. Era o Meyer Fortes em Cambridge, em Oxford tinha o E-P, como eles chamavam, o Radcliffe-Brown (o R-B) - ele e o Evans-Pritchard também eram rivais. Há então o Malinowski em Londres, e o Gluckman em Manchester. Não eram propriamente sete, mas era essa ideia dos sete samurais. Em Oxford, esses caras faziam seminários no pub, eles iam para um bar e, depois que terminava, telefonavam um para o outro: "aquela ideia que nós estávamos discutindo" - e era uma hora da manhã! O Meyer Fortes recebia um telefonema do Radcliffe-Brown dizendo: "olha, aquela ideia é assim, vamos pensar dessa maneira".

Então, tem um elemento de incorporação, de embodiment, como dizem os ingleses (a palavra inglesa às vezes é melhor), havia uma certa incorporação espírita, uma certa mediunidade: os caras viviam aquela antropologia, que acreditavam, praticavam, queriam estabelecer. Queriam mudar a história da antropologia. Malinowski já tinha mudado um pedaço. E eles mudaram mais. Eles queriam ser mais precisos do que Malinowski, eles queriam ser mais "científicos". O Radcliffe-Brown tinha aquela ideia de ciência natural da sociedade, a comparação era uma coisa importante, ele escreveu nos seus livros. E era mais presunçoso em matéria de epistemologia, de teoria, porque tinha lido algumas coisas de biologia, e tinha a carta famosa que ele escreveu para o Durkheim. O Durkheim leu a tese dele sobre os Andamaneses, que os ingleses sabiam que a pesquisa tinha sido feita num hotel, ele não fez como o Malinowski. Imaginem! Vocês leram aquele diário do Malinowski? Eu li e voltei à tortura que vivi com os Gaviões... De noite, ele ainda tomava aquelas injeções todas que matavam, porque ele era tuberculoso! Fazia exercício... Esse homem morreu aos 54 anos, no meio de um coquetel na Universidade de Yale, caiu duro! Fulminado por um ataque cardíaco aos cinquenta e poucos anos. Imagina se ele tivesse vivido mais uns 20 anos, o que ele não iria fazer? Então, uma das coisas que mais me impressionou no diário de campo, primeiro foi o negócio da sexualidade, porque esse cara era um polonês, então ele não tinha que esconder muito, não é? O diário é secreto! É um diário que ele fez para ele mesmo, era uma maneira de desabafar, porque fazer pesquisa de campo é complicado ...

M.L.V.C.C. Mas quando você fala dos africanistas que mudaram o curso da antropologia, é esse grupo?

R.M. Bem, o Evans-Pritchard era um sujeito genial, esse não chegou ao estatuto lévistraussiano porque ele não era francês, era inglês. Eu não o conheci pessoalmente, mas o folclore em relação a ele era imenso, a bissexualidade, e o departamento de Oxford refletia essa personalidade múltipla. O seu interesse em História, no lado romântico da antropologia. Quando Radcliffe-Brown - R-B, 
como eles diziam - estava falando de ciência natural da sociedade, E-P estava escrevendo e dando uma aula de história da antropologia! Claro que ficando do lado da antropologia, mas dizendo que a antropologia é uma ciência histórica, ela é idiossincrática, não é nomotética. Ele estava falando isso! E fez uma história dos Sanusi da Cirenaica, na Costa Norte da África, que é o primeiro livro dele, e é de História! Ele não fez esse livro à toa! Ele disse: "eu vou mostrar para esses funcionalistas que estão falando de estrutura...". O primeiro artigo que saiu sobre estrutura social foi o do Meyer Fortes, "Time and social structure". É um artigo em que ele define estrutura social no estilo inglês. O que é estrutura social? São as relações observáveis, que são fixas entre os seres humanos em qualquer sociedade. O Lévi-Strauss não, ele tem um modelo muito mais sofisticado, "a realidade não existe", "a realidade é representada", é mais durkheimiano nesse sentido, é uma maneira de ler o mundo, é uma coisa mais complexa. Mas esses africanistas são muito bons. O Beidelman escreveu uma vasta bibliografia, os livros propriamente não têm muito pé nem cabeça, mas tem uns artigos maravilhosos que são análises na base antropológica, não estrutural, mas funcional, de folclore africano, a Hiena e o Coelho - como tem, na Índia, o Corvo e o Pardal. Pela primeira vez na minha vida, nesses seminários do Beidelman nos anos I960, eu tive uma aula: a hiena não é pai, ela se associa com o coelho, que é um tio materno - é uma sociedade matrilinear. Ele mostrava como o conto folclórico reflete e reproduz a estrutura social com algumas inversões, mas não chega ao nível de abstração e nem àqueles insights lévistraussianos em que você começa a ter uma visão distanciada de uma forma de pensamento que não tem nada a ver com a tradição europeia, que tem a ver com o corpo humano, com a qualidade dos objetos, com a lógica da qualidade sensível de 0 cru e o cozido, que é um empreitada intelectual revolucionária. Não tem uma ideia de que o mito se esgota em si próprio, ao contrário, cada mito reflete o outro, é uma explosão que dinamitou toda a análise semântica, toda a análise literária.

Luiz Costa Lima escreveu um livro muito bom, Estruturalismo e teoria literária. Eu reli agora, recentemente, e é interessante, são notas sobre o Lévi-Strauss, só no final é que tem um capítulo pequeno em que ele vai aplicar aquilo à literatura. Affonso Romano de Sant'Anna também escreveu. Num sentido preciso, o estruturalismo lévistraussiano surgiu na PUC, o funcionalista no Museu. E eu fiquei com a cabeça a mil, fazendo esse curso com Tom Beidelman, lendo O pensamento selvagem, o Totemisme aujourd'hui.

Um dia, fui assistir a um filme em Cambridge, no Brattle Theatre, que era um cinema que só passava filme antigo - hoje é moda, hoje todo mundo passa filme antigo! Nos Estados Unidos, naquela época tinha dois cinemas assim, Nova York tinha um, e lá em Cambridge, os harvadianos tinham esse Brattle Theatre. Lá eu assisti três filmes com Humphrey Bogart, da década de I940, inclusive o "Casablanca" que eu não tinha visto. Mamãe falava muito do filme, tocava no piano "As time goes by"... Bem, em um desses filmes antigos 
que eu fui assistir, não me lembro qual, passava um documentário antes, um desenho animado, que era um conto de Edgar Allan Poe. E eu falei: "Cara! Vou fazer uma análise"... Porque eu tinha lido Edgar Allan Poe, porque eu queria ser escritor, eu não queria ser antropólogo, se eu tivesse estudado numa High School americana, eu teria ido para o departamento de artes, eu ia participar de peça de teatro, eu ia participar do musical e eu ia fazer creative writing. Quanto eu fui para a faculdade, em Niterói, eu queria fazer arquitetura porque gostava de desenhar e de pintar, mas eu não podia, por causa da matemática, então peguei uma coisa no meio, fui fazer um curso de história, que é uma disciplina apropriada, porque na história você pode usar sua imaginação, inventar e ao mesmo tempo fingir que trabalha com alguma coisa concreta. Eu queria entender certas coisas que faziam parte da história da minha família e da minha própria história. Encontrei a antropologia, e tive a sorte de ser aluno do Castro Faria, que me levou para o Roberto Cardoso de Oliveira. Lá, com o Roberto Cardoso de Oliveira, eu encontrei essa encarnação antropológica, esse embodiment, que depois eu descobri que ele estava fazendo no Brasil sozinho! Depois eu ajudei, depois o Roque Laraia, o Melatti ajudou, foi o que nós fizemos no Museu Nacional: viver a antropologia 24 horas por dia! Era um convento antropológico, tudo girava em torno de antropologia. Era esse negócio de telefonar. Ora, como é que o Roberto Cardoso fez isso? Ele fez isso porque veio do grupo do Florestan Fernandes, que fez isso em São Paulo para a Sociologia. Não eram mais os meninos ricos de classe alta de São Paulo, tipo Oswald [de Andrade], que escreviam sobre tudo, que fez a tese sobre antropofagia, que tinham algumas sacadas maravilhosas, mas não eram profissionais. O Florestan era filho de uma empregada doméstica...

V.S. É, profissionalizou.

R.M. O Florestan é aquele negócio: ou entra de cabeça ou não entra, aquele chamado durkheimiano; um modelo medieval, monástico. A gente podia casar - ninguém tinha que fazer um voto de castidade -, mas você tinha que fazer um voto de obediência e, mais que isso, renunciar ao mundo. Era o mesmo modelo Max Gluckman! Isso passa pelo Darcy Ribeiro, e que o Roberto pegou, na primeira vida do Darcy, quando era o homem dos índios, defensor de índios, antes de nascer o Darcy com todo aquele populismo político. O Roberto tinha estudado filosofia, então estava aberto a essa movimentação lévistraussiana.

M.L.V.C.C. Um formador de gente, não é?

R.M. É, formador de gente! E formador de instituições. Roberto era capaz de enfrentar as pessoas. Eu vi várias vezes - para mim era chocante, porque eu sou incapaz de fazer isso até hoje - "Eu discordo de você!" e ele dizia isso sem o menor receio e com um sotaque paulista, sem o menor problema: "Isto que você está falando não é verdade!” Era veemente e pegava você pelo pé. Em I959 
eu visitei a casa do Roberto, no Leme, e ele me deu dois artigos que ele tinha escrito e um deles com uma dedicatória. Era sobre os Terena, "A situação dos Terena". A antropologia brasileira na época era isso: "A situação atual dos Tapirapé", "Os índios Gaviões e o contato com a sociedade nacional", era isso, a gente não entrava por dentro ou falava de dentro. Essa descoberta de pular o muro cultural se abriu para mim a partir desses cursos em Harvard, em i963r964. Eu vi que não sabia nada sobre a vida social dos Apinajé. Fui fazer um seminário sobre os Apinajé falando de contato, e aí um colega me perguntou: "Mas qual é a ideia que eles têm sobre a chefia, eles têm alguma ideia de poder? Como é que se exerce o poder entre os Apinajé?". Aquilo ali ficou gravado na minha cabeça! (risos). Aquilo ficou gravado... eu estava todo errado! Primeiro, tínhamos errado o diagnóstico de um país que tinha mudado: de onde surgiram esses militares? Olha a visão! A minha visão dos grandes atores do Brasil era: o operariado, os sindicatos, e o povo. Mas onde é que ficava o povo? Deram um golpe em 24 horas, e sumiu todo mundo. Muitos foram se refugiar nas embaixadas e quem era rico pegou um avião e foi para Paris, ou Londres, e o resto foi preso! Um amigo meu, que era psiquiatra, foi preso no Estádio Caio Martins - eu visitei ele outro dia e nós tomamos um porre de uísque -, ficou preso durante um mês e meio. Eu provavelmente teria sido preso, como ele. Talvez eu não fosse denunciado porque a inveja que eu despertava naquela época era menor, se fosse hoje eu seria fuzilado! (risos) Mas naquela época eu despertava menos inveja porque eu não existia, eu não era nada, era um menino estudioso de antropologia que dava aulas na Universidade Federal de Fluminense.

Mas, quando eu voltei de Harvard, dessa primeira ida, com todas essas ideias na cabeça, com Mary Douglas, com Victor Turner... Porque o que acontece na antropologia inglesa nesse momento eu não vou repetir aqui o que já escrevi sobre isso, mas há uma transformação e uma descoberta! Era um momento hippie e de crítica ao capitalismo, que é o início de uma pós-modernidade em que esses professores fizeram a antropologia - Edmund Leach, Mary Douglas... Também o Ian Lewis, que era professor da London School, que também era escocês, e escreveu um artigo maravilhoso sobre "o poder dos fracos" e não é mais citado porque "não ficou" - porque tem gente que fica e tem gente que não fica. Esse artigo era sobre a sua pesquisa lá na Somália, e hoje você não pode fazer pesquisa de campo na Somália. Ele foi estudar na Somália e descobriu o poder das mulheres oprimidas: uma mulher quer que o marido dê para ela uma máquina de costura; quem manda na sociedade é o marido. Mas, quando uma mulher pede uma máquina de costura, você tem que pedir dinheiro emprestado para dar a máquina de costura para ela! Senão, ela fica sujeita a receber espíritos malignos! Igual à minha avó, que tinha ataques, caía dura, e aí a família toda se mobilizava em torno de vovó e ela fazia o que queria: queria comprar um chapéu, queria comprar um anel de brilhantes, coisas de mulher... (risos) O sonho de minha mãe era ter um anel de brilhantes cha- 
mado "grão de milho", um brilhante do tamanho de um grão de milho. E papai nunca deu para ela porque esse brilhante custava o preço de um apartamento! Mamãe queria também um piano de cauda, o sonho de minha mãe era um piano de cauda.

M.L.V.C.C. Este sonho é bom!

R.M. A conexão foi essa, quando eu voltei de Cambridge, depois de ter experimentado aquela vida em Harvard, de que até hoje eu tenho saudades, e tenho saudades também de Notre Dame, ${ }^{6}$ porque os escritórios funcionam. A universidade é um estilo de vida, não é um lugar que você vai para estudar, para trabalhar. É tudo: é um fato social total. Tudo ocorre em torno da universidade, você vai jantar com os colegas, você vai beber um drink com os colegas, tem tudo ali. É como Oxford, a cidade é a universidade, e a universidade é uma cidade. Nós não conseguimos fazer isso no Brasil.

M.L.V.C.C. É uma utopia! A biblioteca que fica aberta até onze horas da noite, nos sábados, domingos, feriados.

R.M. Em Harvard fica aberta a noite toda! Quando eu cheguei lá, me alertaram: “Cuidado com a biblioteca!", porque a Widener era a maior biblioteca do mundo - contava-se uma história maravilhosa, de um aluno um tanto incauto que ficou perdido uma semana dentro da biblioteca! (risos) Naufragou! O garoto entrou lá nos labirintos das estantes e não conseguia sair, dormiu a primeira noite e tinha levado um sanduíche, comeu o sanduíche... Foi encontrado de olho esbugalhado, barba por fazer, perdido! História maravilhosa, muito parecida com a história do filme do Stanley Kubrick, O iluminado. Mas o menino se perdeu na biblioteca, é uma história linda! Falaram isso para mim: "você toma cuidado na Widener".

Veja bem: em I963 tinha artigos de antropologia que eram citados, autores que eram citados, por exemplo, do Hocart, que você não tinha nem no Museu Nacional, nem nas bibliotecas da USP. Você tinha que ir para Paris ou para Londres ou para os Estados Unidos, onde esses caras escreveram, onde estão publicados os artigos de Van Gennep sobre "As línguas secretas dos rituais". Eu só ia achar esse artigo em Paris. Hoje você tem a JSTOR, a Capes lhe permite isto, você entra e pega o artigo. Outro dia eu li um artigo muito interessante sobre a noção de corpo nas sociedades ameríndias - porque agora tudo é ameríndio, influenciado pelo Eduardo Viveiros de Castro. Eu li um artigo interessante escrito por uma inglesa sobre a concepção do corpo que não é biológica, que há também um parti pris, mas enfim, eu pude fazer isso. Em I963, eu tive que sair do país para voltar e falar: "o que tem sido discutido é isso ou aquilo!" Falar do impacto da antropologia lévistraussiana e da obra do Rodney Needham, que em I960 tinha tido um impacto muito grande também, quando ele escreveu uma crítica ao livro do David Schneider e do George Hommans. O 
livro do Needham é o Structure and sentiment e ele mostra que Schneider e Hommans não tinham entendido uma passagem crítica de As estruturas elementares do parentesco, que é a distinção entre preferencial e prescritivo. O Lévi-Strauss estaria falando de casamentos prescritivos, e anos depois ele próprio escreveu desmentindo tudo... (risos), que não era nada disso... Em I969, quando fui ao Congresso de Americanistas em Viena, visitei a Europa pela primeira vez e fui visitar o Needham, em Londres. Ele tinha retratos de todos os heróis intelectuais na parede, inclusive o Kant. E ele fazia perguntas, porque ele era professor: "Maria Laura, please tell me, let me see if you really know... Who is this?", e era o retrato do Kant, do Immanuel Kant! "Do you know to whom this picture belong?", Era o retrato do Lévi-Strauss, com a dedicatória que ele pediu ao Lévi-Strauss. Quando eu voltei, anos depois, em 200I, não tinha mais nenhum retrato na parede (risos), ele tinha dado todos os livros de antropologia, ele desistiu de fazer antropologia... Tinha ficado viúvo e morava em um apartamento sozinho, em uma daquelas ruas maravilhosas de Oxford, perto de um pub... Eu fui visitá-lo com Celeste, minha mulher. Antes da visita, ele perguntou para mim o que nós gostaríamos de beber, eu disse: ela bebe um sherry. E tinha um cálice de sherry para Celeste e um copo de uísque para mim. Sem gelo, claro, porque na Inglaterra não tem gelo. Eu brincava com o Maybury-Lewis que todo mundo na Inglaterra tinha essa geladeira pequenininha, dessas que a gente tem no quarto, e o tamanho da geladeira definia o status social da pessoa, porque só tinha geladeira grande, tipo americana, quem era muito rico, e não tinha gelo. Ele tomou um vinho, aí nos serviu, aí sentou na cadeira e fez exatamente as mesmas perguntas que havia feito para mim no escritório dele tantos anos antes. Sentou, cruzou a perna: - "My dear Roberto, please, tell me about your life". "Como é que você está trabalhando com os índios? Você está estudando sistema de parentesco? Como é que você está estudando sistema de parentesco? Quais são os seus findings?" Era assim, ele funcionava...

\section{V.S. A ser ouvido, não é?}

R.M. Os americanos, desde a escola primária, tudo que eles vão fazer está na ponta da língua, eles querem ter sucesso, e eles acreditam que aquela sociedade é uma sociedade em que quem é bom vai ter sucesso, é uma injustiça quando você não tem. Da mesma forma como eles acreditam que o sistema de justiça e o sistema policial, mais cedo ou mais tarde, vai prender os bandidos, pode demorar 30 anos, pode ter erro, mas um dia sai uma reportagem no New Yorker, 30, 40 anos depois mostrando como o bem venceu o mal.

Então cheguei, sentei, conversei com ele, quando chegou no fim da visita, estava com uma máquina fotográfica, e eu perguntei se eu podia tirar um retrato com ele, Celeste tirava o retrato, depois tirávamos nós três: "No, I'm sorry. Só fico para a posteridade com os livros". Então, nos anos I960, eu voltei para o Brasil com esse espírito que encaixou com o do Roberto, a quem nós 
(Roque, Melatti e eu chamávamos de "RCO"). Naturalmente, eu tive a minha cota de angústia de influência com o Castro Faria, mas com o Roberto era enorme. Era um problema, porque, quando eu cheguei, produzi "Edgard Allan Poe, o bricoleur", publicado na revista Comentário, aliás o editor era um cara maravilhoso, muito inteligente e foi quem me apresentou a Hannah Arendt, "Você tem que ler Hannah Arendt" e tal. Os livros sobre totalitarismo e antissemitismo que eu li. Mas eu publiquei o artigo e Maybury-Lewis também ficou uma fera, porque Lévi-Strauss tinha escrito "Os Gatos", junto com Jakobson, que eu tentei ler outro dia e não entendi... (risos)

M.L.V.C.C. É muito difícil aquele artigo, é uma loucura.

R.M. Continuei não entendendo. Já tentei ler 5 vezes (risos).

M.L.V.C.C. Eu tentei duas vezes.

R.M. Eu li com 20 anos, li com 30 anos, li com 40 anos, li com 50 anos, li com 70 e não entendi. Eu desisti! Reli agora, não entendi, "Les chats".

V.S. Sobre o poema de Baudelaire.

R.M. Aí o Maybury-Lewis me escreveu uma carta me condenando... Eu tenho essa correspondência - quando eu morrer, se alguém tiver o cuidado de pegar, vai ver -, ele dizendo: "Eu recebi seu artigo e tal. Os antropólogos com os seus brinquedinhos à la Lévi-Strauss...". Porque o que eu tinha que fazer era estudar organização social.

M.L.V.C.C. E "Panema"? Vem logo depois também, não?

R.M. Pois é, o "Panema" foi o seguinte: eu dei um curso de antropologia brasileira na Universidade Fluminense. Aí você vai ler o quê de antropologia brasileira? Tinha Emilio Willems, tinha o Florestan Fernandes que, depois dos Tupinambás, não estava fazendo propriamente antropologia, fazia uma ciência política, uma sociologia política.

M.L.V.C.C. A não ser o trabalho sobre "As Trocinhas do Bom Retiro"...

R.M. Exatamente. Eu peguei o que eu podia. Então eu entrei na Comunidade amazônica, com o Charles Wagley e o seu ex-aluno, Eduardo Galvão, que eu conhecia pessoalmente, porque a gente ia a Belém fazer pesquisa de campo, tanto o Roque quanto eu, sem dinheiro. Chegamos uma vez em Belém, Celeste, Roque e eu, sem um tostão, eu até conto isso em uma crônica, não sei se vocês leram uma crônica que eu escrevi, chamada "O jantar dos velhos".

M.L.V.C.C. Li!

R.M. A gente leu o cardápio pelo lado direito. Porque eu esperava um dinheiro, um cheque visado que papai ia mandar para mim e o dinheiro não chegou. Nós 
ficamos hospedados no Museu Goeldi. De noite, o Galvão convidava para jantar. Chegava na casa do Galvão e havia pelo menos uma dúzia de cervejas para a gente beber. Ele tomava umas seis enquanto você estava tomando um copo. Ele ia falando, mas a voz ia baixando de tom, no final tinha que ter amplificador para entender. Mas o Galvão recebia nobre e fraternamente e contava. O Galvão estudou em Columbia, foi aluno do Kroeber, ainda pegou o Kroeber, foi colega do Sidney Mintz. Eu encontrei o Sidney Mintz aqui no Rio uma vez e ele me contou que a tese do Galvão, "quem fez a revisão do inglês foi eu", um inglês excelente. Ele escrevia maravilhosamente bem, ele ganhou um prêmio! Ele nunca falou disso para ninguém, era um homem modestíssimo e recebeu o prêmio por ter escrito em Columbia e em inglês, a melhor tese de I949 ou I 948. Este é o Galvão de Santos e visagens, um livro maravilhoso e um sujeito raro, despojado. Eu escrevi agora um memorial para uma homenagem dos Ioo anos de nascimento do Chuck Wagley na reunião de Chicago da American Anthropology Association. Mas eu escrevi porque eu sou muito amigo do genro e da filha dele, o Conrado e a Beth (Isabel Wagley), inclusive visitei os dois agora, eles têm uma casa linda em Carolina do Sul, numa ilha. Eu escrevi isso, rememorando. Peguei as notas de leitura do Wagley e Galvão, um livro todo riscado, Uma comunidade amazônica, é o primeiro estudo de uma comunidade no mundo dos trópicos, que sempre foram tristes e jamais descritos na antropologia. Você sabia mais sobre esquimó do que como aqueles caras na Amazônia viviam, porque há um preconceito contra o calor! Cara, esse mundo é todo eurocentrado! Não pode existir ciência nos trópicos! E quem ia para Paris aprendia isso, voltava para o Brasil e dizia isso aqui, e metia isso na cabeça de todo mundo! Imaginem vocês. No Brasil, nós só fomos descobrir que precisava de escola de engenharia depois da Abolição, é um processo muito lento de retomada de igualdade. O "Panema" foi isso, eu dei um curso na Fluminense, quando eu cheguei nesses dois livros, e que vi o Panema, eu falei: "Ah, isso aqui é meu! Isso aqui é ideal!". E fiz a análise estrutural direitinha, bonitinha, mas naturalmente superficial aos olhos de alguns.

M.L.V.C.C. É muito legal aquilo.

R.M. Exatamente como Lévi-Strauss depois fez no Mythologiques. O que é que sobra? Você analisa cinco mitos, aparentemente eles são todos diferentes, quais são os elementos comuns? Aí eu fiz uma análise estrutural do panema. A história é interessante e agora eu posso contar. Aí eu mostrei para o meu professor... Porque o Needham falou isso para mim: "O que o nosso professor pedia, nós fazíamos". Era o Evans-Pritchard o professor dele. "Se ele falasse: você vai estudar o grupo tal! Nós íamos". Nenhum inglês estudou a Inglaterra, e nem a Europa, era proibido. Você tinha que estudar uma sociedade diferente da sua. Para poder ter o choque do "alter", não pode estudar o mesmo, tem que estudar o outro, o outro absoluto! Então eu mostrei para o meu professor, aí o Roberto 
leu e fez uma crítica, porque naquela época - ele me ajudou muito a escrever bem, o Roberto e a Yonne Leite, que era do departamento de linguística, muito ligada a nós, e ela fazia as revisões, tudo o que era confuso no meu artigo foi sendo clarificado. Essas coisas ficam, não é? Mas tem o trauma que é o seu professor pegar o seu artigo e dizer que está tudo errado, que o que está no fim tinha que ser no início, o que está no início tinha que ser no fim! E eu, naquela época, já tinha recebido essa crítica algumas vezes em outros trabalhos, porque tudo passava pelo nihil obstat do Roberto. Eu fiquei até sem dormir, cheguei em casa triste, era só eu e Celeste naquela época, que maravilha! (risos) Era só eu e ela, ela preparava um jantarzinho para nós dois. Ela me perguntou: "O que você tem?", "Ah, aconteceu isso... o Roberto... e tal". No dia seguinte Roberto foi generoso. Mas o que foi que eu fiz? Como teste, enviei o ensaio para o Papa, o próprio Lévi-Strauss. Eu tenho a carta. Ele fez o artigo ser traduzido e foi o primeiro artigo de um brasileiro publicado na L’Homme. Tá lá. Hoje, no livro que foi publicado no centenário de Lévi-Strauss, meus colegas dizem que nós fizemos leituras superficiais do Lévi-Strauss..., mas esse panema ele gostou tanto que publicou na sua revista. Mas as nossas leituras são superficiais... (risos) Não é bacana? Não é uma boa história?

\section{V.S. É uma ótima história, é muito boa!}

R.M. Nós fizemos leituras superficiais... É claro! Hoje, o cara morreu, e hoje é que a leitura de fato pode ser feita, porque hoje a obra fechou, na época era uma obra aberta. Quando eu estava entre os Apinajé, aquela hipótese de que o fogo entre os Jê foi dado por uma relação de aliança, não é verdade. Ele insiste naquilo, não é? Que é uma relação de cunhados e depois a onça que tem um marido, mas é uma relação de afinidade, no sentido em que a onça, que salva o menino, adota o menino como sobrinho e dá um nome para ele. Isso é uma descoberta muito boa que foi feita depois. Depois que o Melatti, eu e outros demos elementos para que se demonstrasse que as relações de nominação entre os Jê são equivalentes às relações de afinidade. E mesmo assim você tem que abrir muito essas noções e este é o problema das ciências sociais. Se você expandir muito um conceito, ele não serve para nada; se você também reduzir muito, ele só vai servir para um caso. Essa é luta, não é?

Então, o que aconteceu? Eu conheci o Terry Turner - só para mostrar como o tecido da vida é grande, não é? É feito de muitas malhas. Eu conheci o Vic pessoalmente por meio do Terry Turner, que havia sido contratado como professor assistente em Cornell. Foi trabalhar com o Victor Turner, o mesmo sobrenome, os Turners, o Vic tem até um artigo antigo em que ele diz do Terry, "ele é um membro do meu clã". E o Terry era amicíssimo do Vic, adotou o Vic como um pai. O Vic era uma figura paterna, sua mulher, Edie, era inglesa, muito simpática, filha de um médico. Ele dizia: "a Edie tem a mania de curar as pessoas, de dar remédio". Em Virginia, eles tinham uma casa, era uma casa 
simples e enorme. O seminário dos alunos pós-graduados era na casa dele. Naquela época ele tinha publicado um ou dois livros que tinham tido um impacto muito grande. Vejam bem: todo mundo estava falando em estrutura e aparece um cara que diz que a estrutura tem um outro lado! No Brasil, quem ocupa mais ou menos esse lugar é o Bourdieu. Eu não tinha antipatia, mas achava que tudo o que o Bourdieu falava de modo confuso, naquele antropo-francês, o Vic havia dito claramente.

\section{M.L.V.C.C. Exatamente...}

R.M. Toda a estrutura tem um processo, tem os interstícios. Isso encantou a todo mundo. E com um olho aberto para a sociedade ocidental, que é um ponto fundamental, como a Mary Douglas do Purity and danger, que começa estudando o mundo ocidental, a cosmologia hebraica. Então, em ig63, o Terry me convidou para passar um fim de semana em Cornell, ele tinha se divorciado, estava vivendo uma crise, nós almoçamos juntos naquelas cafeterias maravilhosas, enormes, "góticas", tudo falso. Tudo cenário. A América é um cenário real. Não sei nem se a América existe de fato! (risos). Pense na Estátua da Liberdade. É muita metonímia. Bem, mas então, fui à casa do Vic com o Terry. E o Vic, muito simpático, ia apresentar um trabalho em Harvard. Conversamos e eu assisti ao seminário na casa dele. Ofereceu cerveja, todo mundo foi embora e nós ficamos conversando com ele, e ficamos amigos. Em Cambridge, ele fez a palestra, e o Frank Cancian, que tinha trabalhado com rituais dos Zinecantan no México, como colaborador de um professor de Harvard chamado Evon Vogt, um sujeito maravilhoso. Vogtie, como era chamado, dava um curso chamado "Religião nas sociedades primitivas", Primitive religions. E eu fui assistente dele. E quando você tem assistente, você não dá aula. Para isso que você tem os assistentes. (risos) E na primeira aula do curso, às nove horas da manhã, em um dia frio de Cambridge, ele vai mostrar como é que se faz um ritual quando um homem mais velho encontra um homem mais novo lá entre os Zinecantan. Eles têm que tomar uma bênção - coisas do mundo ibérico - e tomar um gole de uma cachaça mexicana, feita de milho. Ele levou a garrafa, botou, eu fiquei pasmo com o pragmatismo. Imagine se o professor de antropologia estivesse mostrando um ritual canibal? Será que ele ia matar uma pessoa?! Ou levar um boneco, para matar, para mostrar como é que faz para comer. Ele tomou aquela cachaça, deu a aula. A segunda aula era minha, e eu dei a aula! Foi uma das melhores experiências da minha vida. Preparei uma aula sobre religião e antropologia, pois a antropologia nasceu com o estudo da religião, com essa visão holística. Quando eu terminei a aula, cinco alunos que ainda podiam escolher qual era o curso que iam fazer, vieram perguntar se era eu que ia dar aquele curso (risos). Eu falei que estava apenas substituindo, e eles disseram "se o curso fosse com você, eu fazia”. Achei ótimo! Mas o Vogt era generosíssimo. E ele queria contratar o Victor Turner. As conferências do Turner ficavam lotadas. 
Ele lia com um inglês com sotaque escocês, ele citava poesia, declamava Shakespeare de cabeça. O Gluckman também, o pai dele era advogado, e lia, de manhã, Shakespeare, fazendo a barba. Fazendo a barba com um olho e com o outro lendo, e recitando. A casa dele era uma casa em que se lia muito. Os caras tinham esse interesse literário e também psicanalítico. O Gluckman foi psicanalisado, então tem muita coisa...

M.L.V.C.C. A ideia de catarse é importante para ele, não é?

R.M. A ideia de que, no ritual (diferentemente das cerimônias), são problemas mais profundos que emergem. Porque o Gluckman tinha contato com o pensamento freudiano. O Turner não sei. Mas o Turner era um verdadeiro vulcão de ideias. Ele deu uma conferência em Harvard, e todos os alunos diziam: "Espero que esse cara seja contratado". Então encontrei com ele e perguntei: "Então tem a communitas, mas a communitas não vira estrutura e a estrutura não vira communitas?" Ele adorou, conversamos e ficamos amigos.

Quando eu voltei, em 1979, convidado pelo Tom Skidmore para passar um ano como Visiting Professor em Wisconsin, eu dei um seminário sobre rituais e era uma maravilha... tinha um salário na época extraordinariamente bom.

V.S. Já tinha publicado Carnavais...?

R.M. Sim, Carnavais saiu quando eu estava em Wisconsin. Eu me lembro que recebi uma carta do Carlos Nelson [Coutinho], com um artigo do Jornal do Brasil sobre Carnavais, malandros e heróis, não sei por quem, e embaixo ele colocava assim: "Você sabe de quem estão falando?". Muito simpático! Então, lá em Wisconsin eu dei um curso sobre rituais, trabalhei muito, e nesse período a grande descoberta intelectual que eu fiz foi "a ética protestante", eu li tudo, inclusive as notas.

M.L.V.C.C. Aí realmente modifica, não é?

R.M. E aconteceu outro fenômeno também importante na minha vida: em paralelo ao Victor Turner, eu descobri a obra do Louis Dumont, que é uma obra hoje muito injustiçada. O que esse cara falou sobre o mundo moderno, sobre a ideologia moderna e o individualismo é fundamental, e um monte de coisas se explicam se você introduzir o individualismo como valor como uma variável ou uma dimensão básica da nossa vida social.

M.L.V.C.C. Roberto, eu não queria deixar de perguntar duas coisas: primeiro, são esses lampejos que foram o "Carnaval como rito de passagem" e o "Carnavais, paradas e procissões". A gente lê hoje e vê que está tudo ali, com uma impressionante sensibilidade para o manejo dos símbolos. E também sobre o seu artigo de 2000, que dialoga com essa turma dos estudos de rituais, que foi publicado na Mana, que é muito interessante também...

R.M. Sobre liminaridade e individualidade! Ali já tem muito do Dumont. 
M.L.V.C.C. Exatamente, eu lembrei porque nele você volta ao Turner de outra maneira...

R.M. Mas ele não gostava... Quando eu encontrei com ele no Japão, em setembro de I98I (ele organizou duas conferências na Coreia e uma no Japão). Na conferência do Japão ele já ficou meio chateado comigo, porque eu falei: "você tem que introduzir instituições, tem um sistema político!” Isso já está em Carnavais, malandros e heróis. A communitas americana é diferente da communitas brasileira.

M.L.V.C.C. Tinha que introduzir a noção de sistema junto com a ideia de communitas.

R.M. O carnaval americano exclui, é um carnaval hierárquico, o carnaval de Nova Orleans é todo hierárquico. Isso eu conversei com o Calvin Trilling, escritor americano que visitou o Brasil e o consulado me chamou e eu conversei com ele. Ele tinha escrito um artigo que eu citei. Um escritor com uma bagagem muito grande de pesquisa, de trabalho, de formação universitária, de conversas. E ele falou: "você está absolutamente correto".

No Japão, teve um dia em que nós pegamos um ônibus. Eu estava de saco cheio com aquela coisa americana de "virar nativo" - passamos uma noite em um monastério coreano e tal. A minha reação foi brasileira. Comida japonesa, café da manhã era sopa de peixe. Aí o Vic Turner falou uma frase, que ele gostava muito de falar, que a communitas criava um não-lugar e um não-tempo. Aí eu falei para ele: "I want a real place and a real time! I am tired of communitas!" (risos). Ele ficou chateado! Mas não falou, porque ele não era de reagir. Mas, ele ficou me olhando...

Mas antes disso, entre I979 e I980, ele me convidou para fazer uma palestra em Virgínia, no departamento dele, ele morreu dando aula lá. Eu fui, cheguei lá e falei um pouco já dessa ideia de liminaridade com individualidade, um pouquinho. O negócio do Dumont entra aí também. Tocqueville disse: “O universo aristocrático e o universo democrático são dois estilos de vida, são duas maneiras pelas quais os homens se exprimem, eles não são mutuamente exclusivos". Eis um insight que contraria a visão rotineira de que uma coisa acaba com a outra. E o Dumont, muito sabiamente, fala da reversão hierárquica. As mulheres são oprimidas em determinadas situações, mas existem outras situações que só as mulheres oprimidas podem fazer. O mesmo ocorre com os "pobres". Eles viram o foco da sociedade, o que não significa que eles não são dominados, que não tem a lógica de subordinação. Mas isso mostra os limites dessas lógicas. Elas não são absolutas. Apresentei isso, o Vic ouviu...

Mas nessa época o grande problema dele era fazer uma festa carnavalesca na casa dele (risos), era a grande preocupação! Ele me convidou, eu era jovem, tinha aquela barba preta, costeleta, então ele falou: "Vamos fazer... we have to organize a carnival party!" A receita era minha, "como tem que ser?". Era no porão. Eu falei que primeiro tinha que comprar luzes vermelhas. Depois 
discos, ele tinha discos brasileiros - tinha Bossa Nova, Astrud Gilberto. Preparamos. Naquele tempo não tinha fita e alguém tinha que tomar conta da vitrola. Agora tem os DJs. Fizemos a festa com bebida livre, uísque - ele bebia muito bem, eram aqueles galões de uísque... Todo mundo tinha que ir fantasiado. Ele desceu comigo, nós entramos para checar o ambiente, acendemos as luzes. Tinha muita luz, "vamos tirar algumas dessas luzes vermelhas", e tiramos. Uma penumbra absoluta. E quando eu sugeri tirar mais uma lâmpada, o Vic falou: "Roberto, que tal colocarmos umas camas, para as coisas ficarem mais fáceis?" (risos). Aí eu percebi o meu exagero! Fizemos uma festa e eu não sei como a casa dele não desabou! As pessoas vieram fantasiadas e ele dizia como as fantasias revelavam a verdade das pessoas: "It's a perfect costume!". Ele comentou comigo quando a esposa de um colega apareceu vestida de prostituta! Todo mundo era jovem! Dançamos a noite toda. Foi a apresentação desse trabalho, "Individualidade e liminaridade", que levou a esse encontro. Isso o justifica.

\section{M.L.V.C.C. Você apresentou isso lá?}

R.M. Apresentei lá e ele nem reagiu. Não reagiu porque na medida em que a carreira dele foi evoluindo ele queria mais teatro, era fascinado pelo teatro. Ele ficou fascinado também com o que hoje a gente chama de neurociência, o último artigo dele é "O lado direito e o lado esquerdo do cérebro", um é communitas e o outro é estrutura. Esse período em Virgínia estreitou as nossas relações. Eu fiquei hospedado na casa dele. Depois houve o convite para vir para o Brasil, que também não foi fácil passar no Museu Nacional. It was not easy! Eu falava: "Estamos trazendo um grande antropólogo!"

M.L.V.C.C. Você já tinha editado o "Processo ritual" quando ele veio?

R.M. Já, eu tinha aquela coleção, a coleção era minha e do Castro Faria. A Rose Muraro era muito minha amiga. Tinha um dinheiro do CNPq, enfim, essas coisas que a gente pega um pouquinho aqui e um pouquinho ali para trazer o Turner, tinha um pouco da Fundação Ford. Foi uma discussão enorme, mas no fim todo mundo concordou... Ele veio e ficou hospedado na minha casa, ficou um mês lá em casa, junto com o Tony Seeger. O Tony chegou até em um dia de Carnaval, e nós fomos ver o desfile das escolas de samba. Não tinha sambódromo, mas era na rua do sambódromo.

M.L.V.C.C. Era na Marquês de Sapucaí.

R.M. Tínhamos uma pequena verba de pesquisa, sabe quem me deu a verba de pesquisa? O velho Manuel Diégues Júnior que era diretor da Secretaria de Cultura do Ministério da Educação. Se vocês pegarem Carnavais, malandros e heróis verão um agradecimento especial a ele, que ajudou a estudar um assunto que não era estudado. "Você é muito esperto, como você conseguiu receber dinheiro para estudar carnaval?”, uma pessoa um dia me perguntou. Fomos fazer o 
estudo do Carnaval. Eu publiquei Carnavais, malandros e heróis depois. O Vic leu aquilo e publicou um artigo também sobre Carnaval.7 Nós todos somos ladrões, não é? "Tem uma ideia boa de um cara da América do Sul..." Vocês leram o último livro do Marshall Sahlins, Human nature?

\section{M.L.V.C.C. e V.S. Não.}

R.M. Ele usa um monte de coisas do Eduardo Viveiros. Ele cita, mas o livro não é do Eduardo. Você sabe qual é a conclusão do Marshal Sahlins? "Human nature is culture". Zero. Voltamos ao ponto zero. Mas quem tem a consciência de que "human nature is culture" é um membro de uma sociedade que inventou a "human nature", e esse é um problema complicado, não é? Porque se você falar que "human nature" não existe, e ela é "culture", você está reduzindo natureza humana a cultura. Mas há culturas (como a nossa) com ideias precisas sobre isso. Agora voltou todo o problema dos Ianomami de novo, com esse filme do Padilha... Eu assisti ao filme anterior feito por uma moça desconhecida, mas o filme do Padilha é aquela coisa, entrevistando antropólogos americanos, "os segredos da tribo" são os segredos dos antropólogos. O filme é sobre esse abuso cometido com base no eurocentrismo e no colonialismo Ocidental, que era também interno no Brasil. Eu fui para os Apinajés, o Melatti foi para os Krahó - de repente aparecemos... O Maybury-Lewis foi estudar os Xavante - de repente aparece um inglês com uma dinamarquesa: "o que vocês vieram fazer aqui?", "nós viemos..."

M.L.V.C.C. ... "Nós viemos saber quem vocês são!"

R.M. Você sabe o que o Nimuendajú dizia? "Eu não sou brasileiro e eu andei procurando um grupo para morar, para viver, e nenhum deles era bom e me falaram que o de vocês era um grupo muito bom, então eu vou morar aqui com vocês, durante um período". Aí os caras: "Claro! Seja bem-vindo!"

Bem, minha ligação com o Turner se fortaleceu assim e, em I979-I980, quando ele veio para o Brasil, ficou lá em casa, ficamos amigos. Quando ele morreu, eu fiquei muito triste. Ele morreu aos 65 anos, em I983, de um ataque cardíaco. Logo depois eu visitei a Edith, em Virgínia, e ela me ofereceu o quarto deles e foi dormir no quarto de hóspedes. Eu dormi na cama deles. Eu não dormi, não consegui dormir. Não preguei o olho, porque eu queria vê-lo! A presença dele era tão forte. Infelizmente eu não vejo fantasmas. Lamento. Quando eu li "Chihamba, the white spirit" na década de i96o, e depois li recentemente, porque eu estava escrevendo uma crônica, me lembrei de Moby Dick e neste ensaio tem uma análise que ele faz da baleia branca, do branco como fantasmagórico, porque o branco é a súbita presença do luminoso, do luminoso transcendental que aparece no William Blake, o qual ele cita. Amigos, foi quando eu vi mais de cinquenta páginas de detalhes etnográficos precisos. E vocês sabem quem fazia parte do detalhe nas pesquisas? Era a Edith, a mulher 
do Vic, era ela! Eu peguei as cadernetas de campo dele, lá em Chicago. Estava tudo jogado lá no quarto das crianças onde eu dormi. Peguei para ler. Era ela que fazia tudo, os desenhos também. Pensei em roubar, mas não tive coragem (risos). Quando eles foram ver a Umbanda com a Yvonne [Maggie] - pelo que me contaram, eu não assisti -, ele perguntou: "Mas por que tem bambu? Por que tem bananeira?" Na decoração do terreiro, tinha essas plantas. Por quê? Isso aconteceu comigo em Harvard. "Mas os Apinajé?" "Tudo bem que você está falando que eles são oprimidos pelos brasileiros, realmente, não há dúvidas, mas e o chefe Apinajé? Ele é um empregado dos brasileiros? Como é a chefia tradicional? Você fez alguma pergunta sobre isso? O chefe é hereditário? Ele é ao mesmo tempo um sacerdote?"

V.S. É um treinamento, não é?

R.M. Porque toda a nossa orientação era indigenista, apesar do Cardoso reagindo, mas é muito difícil andar contra a corrente. O velho Durkheim, não é? As coerções são sempre muito grandes, o todo nos sufoca. Você vira brasileiro ou estrangeiro sem querer, ou melhor, querendo ou não.

M.L.V.C.C. Mas você encontrou suas brechas, não é?

R.M. Você encontra as brechas e apanha muito, apanha muito para encontrar as brechas. Em I964, conheci pessoalmente o Roman Jakobson. Levado pelo Pierre Maranda, assisti à última aula que ele deu em Harvard. Então Jakobson terminou a aula e foi aplaudido pelos alunos. Porque em Harvard... em Harvard, Chicago, Princeton, Oxford quando o curso é bom os alunos te aplaudem. Aqui no Brasil... Bem, nós somos portugueses, não é?

M.L.V.C.C. Acho que está ótimo. Muito obrigada!

R.M. Eu sou um marginal.

Entrevista concedida em 4 de abril de 2013, na sala do Prof. Roberto DaMatta, no Departamento de Sociologia e Política da PUC-Rio. 


\section{YVONNE MAGGIE}

Maria Laura Viveiros de Castro Cavalcanti. Pensamos em recompor com você o momento do Guerra de Orixá e de seu contato com a ideia de drama social de Victor Turner. No artigo "Social dramas in Brazilian umbanda: the dialetics of meaning", Victor Turner ${ }^{8}$ fala da ida a um terreiro com você, comenta bastante a sua pesquisa. Enfim, queríamos, Giselle e eu, conversar sobre esse momento de recepção da obra do Victor Turner pela antropologia no Brasil.

Yvonne Maggie. Minha pesquisa no terreiro para o Guerra de Orixá foi uma sorte na minha vida. Eu queria estudar umbanda, era muito nova e tinha lido muito sobre os cultos afro-brasileiros em um curso lá na antiga Campanha de Defesa do Folclore Brasileiro. Depois tinha feito o mestrado, tinha ido para os Estados Unidos, tinha aprimorado minhas leituras. Houve também um curso que fiz com o Moacir Palmeira durante o mestrado no Museu Nacional - eu nunca falo disso, mas esse curso foi importante.

M.L.V.C.C. Estamos falando de que ano?

Y.M. Eu entrei no mestrado em I969, o curso do Moacir deve ter sido em I970, antes de eu ir para os Estados Unidos. Eu já fui com a cabeça muito organizada, no sentido da releitura desse material sobre cultos afro-brasileiros. O curso do Moacir nos fez abrir a cabeça. Mesmo dentro do marxismo, era contra o evolucionismo, e fazia com que olhássemos as premissas das quais os autores partiam. A tese de doutorado do Moacir, defendida na França, foi sobre o Brasil Colônia e as várias versões existentes sobre o Brasil Colônia, se era escravista, feudal ou pré-capitalista... Enfim, ele trabalhou com os autores que haviam estudado esse momento - Caio Prado Jr., Celso Furtado, Nelson Werneck Sodré... Comparou os dados respectivos e percebeu que eles trabalhavam com os mesmos materiais. Só que por conta das suas premissas, do seu pensamento mesmo e do que eles queriam provar, apostavam em caminhos diferentes: um dizia: "Não, isso aqui é pré-capitalista!" O outro dizia: "Isso aqui é escravista" e tal... Eu fiquei com essa ideia. Quando eu fui para os Estados Unidos, em I971, na Universidade do Texas, em Austin, passei um ano naquela biblioteca que me influenciou demais - mais do que os cursos que eu fiz lá e tudo o mais - porque foi mais um ano de mergulho na literatura sobre os cultos afro-brasileiros. Comecei a ler nessa perspectiva e vi como a busca de origens para esses cultos era meio nonsense. Quando voltei, em I973, procurei o Roberto DaMatta e ele estava trabalhando com rituais da sociedade brasileira. Fiz com ele um curso de teoria antropológica e ele leu conosco o Victor Turner. Discutimos Durkheim e toda a influência que o Roberto DaMatta tinha recebido nos Estados Unidos, quando teve contato com a literatura de Manchester, do Max Gluckman e do Victor Turner... da Mary Douglas etc. Discutíamos a contribuição desses autores 
para a compreensão da sociedade sem vê-la como altamente estruturada ou anômica; organizada ou bagunçada... Isso me influenciou muito e pedi ao Roberto DaMatta que me orientasse na pesquisa de mestrado. Nessa época, ele ainda era muito ligado ao Roberto Cardoso, que foi o grande fundador do Programa de Pós-Graduação do Museu Nacional. Eu sempre achava que tinha de estudar mais, ler mais teoria. Mas um dia a Lygia Sigaud, que na época era minha colega, me disse: - "Mas Yvonne, vai embora! Vai fazer sua pesquisa!" Eu já dava aula no IFCS [Instituto de Filosofia e Ciências Sociais] e no dia seguinte um aluno do meu curso me convidou para a inauguração de um terreiro. Eu falei: "Vou!", com aquele medo que a gente tem nessas horas.

Giselle Lage. Você dava aula de antropologia no IFCS?

Y.M. Eu fui contratada em março de I 969 e dava cursos sobre o negro na sociedade brasileira, sobre religião e cursos de introdução à antropologia. A nossa entrada no IFCS foi muito repentina, não tinha ninguém. Nossos professores tinham sido aposentados. Eu fiz todo o mestrado, que durou quatro anos, dando aula. O Eremildo Viana, o grande dedo-duro que denunciou muitos colegas e professores chegou a ser chefe do Departamento de Ciências Sociais. Vivíamos em tempos de ditadura e o IFCS foi uma das unidades universitárias mais atingida pela repressão.

A sorte e ao mesmo tempo a formação, a boa formação, me levaram a aproveitar aquele momento. Se eu tivesse tido outra formação eu não teria olhado aquele terreiro daquela maneira. Eu tinha dois interlocutores claros, o Gilberto [Velho], que era meu marido, e tinha muita aflição dessas minhas idas à noite lá para o Andaraí, e uma amiga, a Vera Barrouin Machado - hoje embaixadora do Brasil junto à União Europeia, com quem tenho grande dívida de gratidão, pois em vez de ir para a minha casa, quando eu chegava de manhã do terreiro eu ia para a casa dela. Ela tinha os filhos pequenos e eu contava tudo que tinha acontecido. Porque eu caí dentro de uma crise, que foi se revelando cada dia mais intensa ali naquele terreiro diminuto. Mas se eu não tivesse lido o Victor Turner, se eu não tivesse feito esse curso com o Roberto DaMatta, revendo essa questão da anomia, eu teria interpretado todo aquele conflito como uma desorganização. Eu sempre gostei de ter interlocutores, pessoas com quem eu pudesse falar diretamente. Hoje em dia, quando estou escrevendo sobre alguma coisa, me correspondo com amigos por e-mail. Tenho guardado, desde 2004, todos os meus e-mails para esses meus interlocutores especiais. Então, eu recupero muitas ideias a partir daí. Nessa época, não havia e-mails e a comunicação era pessoal. Então Vera foi grande interlocutora porque gostava de ouvir minhas histórias. Mas eu ficava assim: "Meu Deus, esse terreiro vai acabar e eu estou no meio dessa briga!" Eu estava consciente de que tinha alguma participação na briga... Depois o Roberto DaMatta escreveu Carnavais, malandros e heróis. Não sei se ele já tinha escrito "Panema" e os outros ensaios do Antro- 
pologia estrutural naquela época. Ele falava muito dos Jê, mas já estava começando a pesquisa sobre o carnaval e discutia muito ritual. Se eu não tivesse feito esse curso, eu teria ido ao terreiro e teria desistido, porque na época todo mundo buscava as casas mais famosas e tradicionais. Nisso o Gilberto me ajudou muito, porque muitas vezes eu falava: "Meu Deus! Isso não vai ser uma boa antropologia, porque eu não estou em um bom terreiro". (risos) E ele me falava: "Vai ser sim, vai. Porque você está vendo o que ninguém viu antes". Embora, eu sempre tivesse sabido, pelas leituras dos clássicos sobre cultos afro-brasileiros, que a criação de um novo terreiro foi sempre feita por briga, por fissão interna, era ousado estudar exatamente esse momento que era meio tabu na literatura. Desde o terreiro Casa Branca, em Salvador, que por fissão e conflito por sucessão vê surgir duas novas casas, o Gantois, de um lado e, de outro lado, o Ilê Axê Apô Afonjá. Essa historinha é sempre relatada pelos autores. Não pelo Nina Rodrigues, mas pelo Arthur Ramos, mas fala-se en passant, em pé de página, porque não davam importância a isso, pois enfatizavam os aspectos comunitários, de consenso. O tema do conflito era tabu. E eu, como vocês sabem, gosto de briga. Tem uma certa proximidade entre a personalidade do pesquisador e o que ele estuda. Tenho nove irmãos, perdemos os pais cedo, sempre comprei todas as brigas da família, criei esses irmãos na briga. O conflito no terreiro era estimulante: “O que vai acontecer amanhã?”, eu me perguntava. Tive uma espécie de sorte, pois se eu chegasse num terreiro em que estivesse tudo calmo, eu não teria feito um livro tão surpreendente para mim mesma, eu não teria incorporado, como incorporei, o Victor Turner. Porque, justamente, ele falava das pessoas concretas.

Eu havia lido também o Max Gluckman e a Mary Douglas. Toda a questão dos símbolos que passava pela vida das pessoas, e que eles analisavam a partir da experiência. Até hoje, quando eu começo a descarnar muito o que estou escrevendo, fico aflita: "Quem são essas pessoas?" Nas pesquisas sobre escolas, sempre falo: "Cadê os personagens?" Porque os personagens de Guerra de Orixá carregavam aquelas ideias e na literatura sobre cultos afro-brasileiros que eu conhecia era muito difícil encontrar as pessoas.

M.L.V.C.C. Encontrar alguém de fato, não é? Embora eles estivessem ali...

Y.M. Então, eu tinha poucas referências. A mais importante foi a de Nina Rodrigues, claro, foi a primeira coisa que eu li e falei: "É isso!" Porque o Nina Rodrigues, em $\mathrm{O}$ animismo fetichista dos negros baianos, descreve pela primeira vez como ele entra no terreiro, como ele foi lá, e fala das brigas. É a primeira etnografia urbana brasileira. Claro que com aquele linguajar do século XIX, do início do século XX. Em I967, eu tinha ganho Cidade das mulheres, da Ruth Landes. Logo que saiu a tradução, o Gilberto me deu o livro, que tenho até hoje com a dedicatória dele. Eu fiquei muito impressionada com o livro, porque é quase 
um romance. É uma espécie de história contada dos personagens e é através dos personagens que vamos vendo como tudo aquilo funciona.

No caso do Rio de Janeiro, As religiões do Rio, do João do Rio, foi uma descoberta também. Muito cedo eu li esses três autores que me influenciaram muito na forma de escrever. O Victor Turner foi importantíssimo, mas como redigir a etnografia? Se eu fosse fazer como o Turner em Drums of affliction e em Schism and continuity, seria muito difícil, porque eu não tinha tanto material e também não tinha a estrutura de parentesco... Quando eu estava redigindo, estava em grande moda o livro A erva do diabo, do antropólogo americano Carlos Castañeda. Eu tive esse clique: vou fazer como está no meu diário de campo! Dia após dia. Vou contar dessa forma. Lendo o drama do Turner, vi que o drama podia ser um instrumento de descrição também. Eu tinha uma influência estruturalista muito grande, e o livro tem esse lado de ver os princípios que organizam as condutas, a lógica que estrutura a história. Eu tinha uma noção clara dos princípios gramaticais inconscientes. Aquelas pessoas que estavam ali naquela briga representavam o código do santo e o código burocrático, mas eles não eram aquilo de modo consciente. O Turner me ajudou muito nessa abordagem, como uma forma de pensar, além de ajudar também a perceber como uma estrutura vai se transformando, sem mudar necessariamente. Apesar do rompimento e da separação, os terreiros continuavam sendo organizados do mesmo modo. Não há uma ruptura na forma de estruturar... Mas, ao mesmo tempo, isso tudo era também uma forma de descrever.

M.L.V.C.C. Perceber como o conflito faz parte da continuidade de alguma coisa, não é?

Y.M. Escrever foi a parte mais difícil. Um dia, estava conversando com o Sérgio Santeiro - ele fez sociologia, mas não era antropólogo, é cineasta - e falei: "Não sei por onde eu começo". Comecei a contar e ele disse: -"Mas Yvonne, isso é a boa parte! Você nunca mais vai ter isso!" Foi um verão inteiro, eu escrevi entre dezembro e março, em um calor infernal no Rio de Janeiro. No final, a máquina de escrever estava toda quebrada, estropiada.

Bem, então a ideia muito simples do drama social como tendo as fases do começo, da liminaridade etc., foi providencial. Depois muitas pessoas disseram: "Você tem que ampliar, tem que ir para outros terreiros". Eu tentei, depois, fazer observação participante em vários terreiros, até que tive a ideia que foi elaborada na minha tese de doutoramento, que também virou livro, Medo do feitiço. Escolhi o tema da repressão justamente porque assim eu via a relação entre os terreiros, via como o mundo dos terreiros era criado na relação com o Estado. Foi uma elaboração muito maior e mais demorada. Sempre fui muito lenta nas minhas coisas. Nesse ínterim, depois do final do Guerra de Orixá, quando eu estava pesquisando no terreiro da Dona Conceição, lá em Miguel Couto, o Victor Turner chegou ao Rio... 
M.L.V.C.C. Foi em 1978.

Y.M. Eu tive esse papel... Eu ciceroneei muitos antropólogos a terreiros do Rio de Janeiro e de São Paulo. Levei Marshall Sahlins, o Adam Kuper, entre outros... Mas a ida com o Victor Turner foi surpreendente, maravilhosa, porque eu tinha aquela aversão a esse assunto de origens e de África. Era tudo muito difícil, ainda era ditadura e tinha a polícia perguntando o que você estava fazendo ali. Eu havia morado nesse terreiro durante um mês, conhecia todas as pessoas e levei o casal Turner para um dia comum, uma sessão que eles estavam batendo lá, acho que para Oxum. Era uma casa muito bonita. Era um barracão em um quintal, sabe, essas coisas bem da Baixada Fluminense, aquele terreno muito grande com várias casas - a casa da Dona Conceição e as outras casas de irmãs e da própria mãe de sangue da Dona Conceição que morava lá. Já estava ocorrendo todo esse movimento de trânsito religioso, esse processo de ter sido de umbanda e virar para o candomblé; e de ter sido de umbanda e virar pentecostal e evangélico e tal. O terreiro era bonito porque tinha a casa da Dona Conceição e nos fundos tinha o Tempo, que era uma árvore muito bonita bem no meio, entre a casa e o barracão, sempre pintado de branco, com aquela saia, aquele pano em volta, sempre com uma oferenda aos pés da grande árvore. $O$ barracão era muito lindo, uma coisa simplíssima de chão de terra e o telhado já de armação de madeira, para o que eu, aliás, contribuí. E lá, quando começava a sessão, eles jogavam umas folhas. Não sei se a folha tinha algum significado no ritual, mas eu sempre achei que era para não levantar muita poeira, porque aquele chão era de terra batida, e eles molhavam e jogavam muitas folhinhas de fícus, umas folhas pequenas. Quando eu entrei com o Turner e a Eddie, ele olhou para aquele chão e falou pra mim: "Igualzinho aos Ndembu!" Quando começou a sessão, ele falou mais uma vez: "Igualzinho aos Ndembu!" Porque eles faziam a roda, começavam a tocar os pontos, e as pessoas começavam a entrar em transe. O tempo todo ele dizia: "realmente, isso é igualzinho aos Ndembu!" Aquilo começou a me irritar um pouco, entendeu? Eu queria que ele falasse sobre o terreiro. E a Eddie fez um comentário que na época me chocou muito, porque a Dona Conceição devia ter uns 50 anos. Era uma senhora gorda, poderosa, mandava em todo mundo! A Eddie me disse: "Eu acho que essa senhora está na menopausa". Para mim aquilo era função da mãe de santo. O poder era exercido por ela de uma forma brutal, mas hoje em dia acho que a Eddie talvez tivesse razão. Eu tinha 30 e poucos anos, nem sabia como era esse negócio de menopausa.

M.L.V.C.C. O Roberto DaMatta me contou na entrevista que, quando o Turner lhe apresentou a Eddie, disse assim: "A minha mulher é filha de médicos, ela tem mania de saber a doença dos outros".

Y.M. Isso eu não sabia... Então foi uma noite muito interessante pelo fato de ele estar o tempo todo se referindo aos Ndembu e dizendo que achava que a 
África era importante e que eu não devia ter esse medo de comparar terreiros. Quando ele escreveu sobre isso e me mandou ainda o primeiro manuscrito eu respondi, mas não sei se eu fui educada o suficiente. Aí já tinha o meu filho Domingos pequeno e a gente falava tudo rápido, não tinha e-mail, era tudo difícil, tinha que mandar uma carta...

G.L. Ele lhe mandou o manuscrito disso que viria a ser esse artigo?

Y.M. É, e eu não me lembro onde eu pus isso, procurei, mas não achei. Tenho sempre essa culpa, queria ter ido visitá-los em Virginia, antes de o Turner morrer.

G.L. Tenho uma pergunta específica sobre o conceito de drama. Porque neste artigo, quando vai rever o seu texto, o Turner faz uma crítica à terceira fase, não é? Ele diz que não encontra na terceira fase a reparação na forma como você descreve o drama. Você já parou para pensar se é isso mesmo?

Y.M. Não, não. O que houve foi a fissão, pois, no caso, não houve a possibilidade de equilibrar as duas facções. Em outros terreiros pode acontecer de ter uma crise e o terreiro se recompor. Mas de qualquer maneira, recompõe. Eu não conto isso porque ainda não tinha acontecido. O Mário vai e cria o seu próprio terreiro. E as outras pessoas devem ter se integrado a outros terreiros. Mas eu não sou muito precisa. E nem o Turner é. Ele é meio bagunçado.

M.L.V.C.C. Mas de quem foi a ideia de levar ele lá no terreiro?

Y.M. Acho que foi do Roberto DaMatta ou do Gilberto. Eu tinha um pouco essa função de levar antropólogos famosos aos terreiros do Rio. O meu inglês se fortaleceu muito nessas idas. Porque como é que você traduz todo o ritual para uma pessoa? Bom, para o Turner não precisava traduzir porque ele sabia. Mas, por exemplo, uma vez eu levei o Carlo Ginzburg, historiador italiano que estudou possessão, feitiçaria na Idade Média, e eu achei que ia ser tranquilo. Levei-o em um terreiro de umbanda simpaticíssimo em Botafogo. Descia um monte de pomba-gira, tinha pólvora, sabe? Imagina que o cara começou a passar mal. Acho que ele nunca tinha visto um transe de verdade! (risos) Ele começou a passar mal, pediu para sair, disse que estava com uma alergia. Ele ficou foi com medo! Mas o Turner foi uma visita agradabilíssima e uma boa dica para eu deixar de ter culpa, de um lado, de estar fazendo esse estudo em uma sociedade complexa. Ele achava que isso não inviabilizaria um estudo do ritual, que eu devia aprofundar mesmo e fazer em outros terreiros.

M.L.V.C.C. É. Ele é muito correto no artigo, não é? Transcreve trechos inteiros da sua pesquisa.

Y.M. Mas é engraçado, acho que eu e o Turner tivemos uma relação intelectual mesmo, mais do que de amizade, de afetividade mesmo. Não sei se a presença 
da mulher dele me inibiu um pouco, porque ela era um tipo de mulher diferente da minha geração, que já não era mais assim. O Turner pertencia a uma geração de antropólogos que se casaram com mulheres, às vezes até antropólogas, que faziam esse papel de secretariar, de cuidar da obra do marido. E eu queria muito fazer minha própria obra. Nem tinha exatamente essa consciência, porque acho que a minha relação com a antropologia foi realmente visceral. Eu não tinha, como vejo hoje, os jovens e as jovens antropólogas com uma consciência profissional grande: tem de escrever tantos artigos, tem de sei lá o que mais. Para mim, não tinha nada. Eu gostava de fazer aquilo, quando terminei o mestrado não quis fazer logo o doutorado. Fiquei com aquelas críticas na cabeça, que não eram só críticas, eram também elogios, sugestões. Hoje, olhando assim, não sei qual a impressão que os mais novos têm, não é?

M.L.V.C.C. O seu livro, as pessoas gostam. Leem e gostam.

Y.M. Mas naquela época foi um espanto. Em I975, quando saiu a primeira edição, foi um espanto porque teve até a resenha do Jornal do Brasil, que na época era o jornal que mais tinha resenhas.

M.L.V.C.C. Tinha o "Caderno Ideias".

Y.M. Saiu uma resenha na primeira página do "Caderno Ideias", aliás, os dois, Guerra de Orixá e $O$ medo do feitiço. Este último foi até uma semana antes da defesa. Alguém soube e veio me entrevistar. No Guerra de Orixá, era a Danusia Bárbara, jornalista e hoje crítica da boa culinária, e na resenha Danusia dizia que era o best seller da antropologia. Porque a antropologia era uma ciência muito fechada, muito chata, os autores mais interessantes, como Gilberto Freyre, as pessoas criticavam para caramba. E aí quando chegou o Roberto DaMatta com todas essas ideias da antropologia social inglesa, ele era vibrante, como continua sendo. Trouxe uma antropologia sem medo de ser feliz! Com todo aquele instrumental.

Sempre me afligi com a antropologia que se dedicou ao estudo da religião afro-brasileira que se apoiou no difusionismo. Perguntava aos africanistas a razão dessa escolha. Eu comentei isso com Victor Turner. Como a antropologia que estudou a África Oriental ou a África Central, enfim, era muito mais interessante do que esse pessoal que tinha estudado mais a religião dos Banto, como o Herkovitz, e o Arthur Ramos se apoiando no Frobenius. Turner e o seu mestre, Gluckman, revolucionaram esses estudos a partir da análise do ritual. Esse instrumental todo que o Roberto DaMatta trouxe era uma forma de renovação... Eu pensava: "Puxa, o Malinowski tinha essa intenção mesmo de transformar a antropologia em uma coisa popular!” A Margareth Mead, toda essa gente, mas no Brasil, a antropologia antes de Roberto DaMatta e de Gilberto Velho era muito sisuda. Talvez por isso mesmo o meu livro tenha tido críticas 
muito demolidoras. Afinal, o estudo de um terreiro e do conflito nesse terreiro era algo que perturbava a tradição sisuda da nossa disciplina.

\section{M.L.V.C.C. Quem foi a banca?}

Y.M. A banca era muito simples. Naquela época não havia banca pública. Então, foi o Roberto DaMatta, a Francisca Keller Vieira, que faleceu prematuramente, infelizmente, e o Peter Fry. Eu tinha conhecido o Peter em um seminário do ISER [Instituto Superior de Estudos da Religião], quando ainda estava terminando a dissertação. Eu era muito tímida, quase não falava. E vi aquele homem lindo se aproximando. Ele disse: -"Você é a professora que está estudando esse negócio de umbanda? Eu estou interessado nisso". Ele estava chegando. Foi em I972, quando eu voltei dos Estados Unidos. Eu falei: -“É, estou”. Aí ele perguntou: -"Qual o livro que você me recomenda?" Eu disse: -"Acho tudo boring, muito chato. Você só tem três ou quatro livros e se tem. O Nina Rodrigues, a Ruth Landes, o João do Rio...”. E minha visão coincidia com a dele. Antes de vir, ele já havia lido a Ruth Landes em inglês. Tinha lido isso, que já era uma introdução maravilhosa para o candomblé. Não estou me elogiando pessoalmente, mas naqueles anos 1970, Guerra de Orixá teve uma importância muito grande e eu não tinha ideia da dimensão que aquilo estava tomando. Por isso falo também que tive sorte. Nasci num momento muito especial da disciplina no Brasil.

Lembro de uma sistemática no Museu Nacional. Quando o estudante acabava a dissertação, geralmente apresentava o trabalho para professores e colegas antes da defesa. Não havia qualificação, nada disso, mas tinha essa apresentação. E o Moacir Palmeira, que me ajudou tanto por um lado, me tirou o tapete quando eu disse que iria estudar umbanda. Naqueles dias iniciais da minha pesquisa Moacir Palmeira falou: "Mais uma tese sobre umbanda...". Eu fiquei arrasada, mas não desisti do projeto. Naquele dia em que pela primeira vez apresentei os resultados da pesquisa, quando terminei e abri para o debate, Moacir foi o primeiro a fazer um comentário e disse que ficou muito impressionado com o trabalho, mas declarou em alto e bom som: "Ah, só um terreiro... Quero ver a relação com os outros!" Eles acharam pouco. Eu tinha feito um esforço sobre-humano de romper com tudo aquilo que vinha antes. Talvez eu devesse ter ido mais ao terreiro da Rua do Bispo para ver o que eles diziam do outro, entendeu? Mas eu pensava no texto da ponte na Zululândia, do Max Gluckman. Por que eu não podia também?

M.L.V.C.C. Claro. O seu argumento é muito bom: aquele estudo de caso revela a maneira como terreiros de modo geral se reproduzem.

Y.M. Como se reproduzem e como a estrutura permanece. Vendo as pessoas, pessoas específicas. A minha pesquisa, a do Gilberto Velho, a da Maria Júlia Goldwasser sobre o carnaval da Mangueira são pequenas contribuições. Imagina o que esses autores da antropologia inglesa não foram para nós que tínha- 
mos sido formados pelo Nelson Werneck Sodré, Celso Furtado etc... Quando o Celso Furtado voltou do exílio, eu fui ver, com o Luiz Costa Lima, um filme documentário que fizeram sobre ele na França. Ele era um homem lindo, tinha umas mãos enormes. Eu fiquei encantada com aquelas mãos e pensei: "Puxa, esse homem teve tanta importância!" Mas, para mim não tinha mais. Não que não tivesse, claro, era um pensador da vida brasileira e tal. Mas naquele momento, quando voltava do exílio, o que ele falou foi: "Se a gente não se aprofundar realmente na vida brasileira, esquecer dos grandes modelos, a gente não vai entender nunca o Brasil". Naquele momento, eu queria redescobrir o Brasil. Devemos muito a essa literatura, especialmente ao Victor Turner, mas também a Mary Douglas, ao Max Gluckman, não só em termos da antropologia, mas de uma visão do Brasil, de uma forma de fazer etnografia.

\section{M.L.V.C.C. A vivacidade, não é?}

Y.M. A vivacidade de apreensão, e uma coisa que a Mariza Peirano fala: uma boa etnografia não significa necessariamente uma coisa esperta, mas, antes, uma coisa honesta, descrever o que você está vendo, por mais que as pessoas hoje digam que isso não existe. Se você fizer isso, você tem sempre como rever aquilo, retomar aquilo. Eu acho que devemos a introdução dessa literatura ao Roberto DaMatta, que foi o grande mentor disso aqui no Brasil. Foi ele quem traduziu pela primeira vez a Mary Douglas e o Victor Turner. Mas, sobretudo, a essa abordagem tão refrescante do mundo, que não era evolucionista, que não era difusionista, que não era culturalista.

No final do curso com o Roberto DaMatta, em I972, nós lemos o L’homme nu, do Claude Lévi-Strauss. Tinha a discussão elegantérrima com o Turner. O Lévi-Strauss está, é claro, agarrado às suas ideias, mas ele discute com o Turner e, basicamente, entre os dois mon coeur balance (risos).

\section{M.L.V.C.C. Fica com os dois!}

Y.M. Pois é, quando o Victor Turner estava falando sobre o que representava o ritual, a árvore, o branco, a seiva, e relacionando aquele simbolismo da árvore Ndembu com o sistema de parentesco, com o conflito entre a matrilinhagem e a virilocalidade, ele estava dizendo que os símbolos tinham carne, que não eram desprovidos de emoção, digamos assim. Foi assim que eu li sempre o Turner. Ele pensava estruturalmente, mas ele não queria, como você diz no seu artigo sobre o "Drama social", 9 abandonar o que eu chamo de emoção, você está chamando mais de afetividade, não é?

M.L.V.C.C. É.

Y.M. Mas eu acho que é a emoção mesmo. O sentimento que leva a pessoa a ver no branco o sêmen ou o leite materno. E o Lévi-Strauss responde dizendo que para ele os símbolos só têm sentido porque são o arcabouço do mito. Para ele, 
os símbolos não têm vida no sentido de uma vida afetiva. Eles compõem a matéria do mito. E o mito - o pensamento selvagem, a antropologia estrutural, todos aqueles artigos, o Papai Noel, tudo o que ele fala - é como uma orquestra, que tem uma mensagem, toca uma música e cada conjunto de instrumentos tem um papel e representa aquele papel. Na sinfonia, ao final, você ouve o todo. Mas o todo é composto por essas várias introduções do conjunto dos violinos, das harpas, enfim, de cada naipe da orquestra. Acho que ele via a estrutura como uma coisa muito mais no sentido do Freud, de princípio mesmo do inconsciente. Mas o Lévi-Strauss também está preocupado com o sentido do mito. Porque a música tem um sentido. Ela fala alguma coisa. Ela fala por meio desses contrastes; enquanto o oboé faz uma coisa, o violino faz outra. E no todo vai indo, vai indo e fica uma coisa só. No caso do Turner, se você olhar bem, a simbologia não tem limites, pode ser infinita. O ritual é muito mais difícil de você estudar do que o mito, porque é um balaio de gatos mesmo, mas é ao, mesmo tempo, uma coisa que se repete. Toda vez que você entra no terreiro, você vai ver a mesma coisa. Toda vez que você vai assistir a uma sessão espírita...

M.L.V.C.C. Como uma desobsessão.

Y.M. Desobsessão ou uma coisa lá mais intelectualizada de falar com os espíritos. Você tem uma sequência que vai se repetindo mais ou menos igual. No caso do terreiro, eu tenho essa experiência: agora alguém vai entrar em transe na plateia. Assim se reforça a ideia de que o transe é uma coisa que pode pegar em qualquer um, então qualquer um pode ser médium... Agora, lá nesse terreiro da casa da Dona Conceição tinha muito uma coisa chamada surra-de-santo. Eu não sei se hoje ainda tem, mas eu vi coisas muito violentas, vi pessoas se machucando mesmo. Do santo bater a cara da mulher no chão, entendeu? E o Turner entende o ritual a partir dessa repetição que revela a estrutura e a emoção ao mesmo tempo, a diacronia e a sincronia.

G.L. A mãe de santo disse que ele tinha mediunidade. Não disse?

Y.M. É, ela disse para ele isso, no final. Eu não ouvi isso, mas ela falou que ele era filho de Ogum.

G.L. Falou da mulher dele também?

Y.M. Falou, mas eles falam sempre isso. Quem é um grande e poderoso é sempre um filho de Ogum. Eu nunca fui. Mas, eu era mais poderosa que ele, porque ela me definiu como filha de Oxálufan, que era o Oxalá dela. Mas agora, lá em Manaus, uma mãe de santo falou: você não é nada de Oxálufan, você é de Ogum, é guerreira. Eu sou materialista, mas eu acabei participando. Eu acho que o Lévi-Strauss, talvez, nunca dissesse isso, porque ele é, como diz o Pierre Verger de si mesmo, cartesiano demais para ter emoção. 
M.L.V.C.C. Ou para admitir a emoção, não é?

Y.M. Não, para ter mesmo. O Pierre Verger diz isto na última entrevista dele, naquele filme do Lula Buarque de Holanda, quando o Gilberto Gil faz a última entrevista com o grande antropólogo e fotógrafo que escolheu o Brasil como sua terra. E o Pierre Verger diz uma coisa e o Gilberto Gil não escuta. E ele pergunta várias vezes: "Mas você acredita? Mas você acredita nos Orixás?" E o Pierre Verger está dizendo: "Não, eu gosto de ver, mas eu não acredito". E ele não ouve. Até uma hora que ele repete e o Pierre Verger diz: "Você está querendo saber se eu acredito que os Orixás existem? Eu não acredito, eu sou cartesiano demais para ter emoções. E isso me faz sofrer muito". O Evans-Pritchard dizia isso também, de uma forma diferente porque era católico. Ele dizia: "Eu ajo como um zande quando estou entre os Azande, como um Nuer quando estou entre os Nuer e como um inglês quando estou na Inglaterra. Quando estou aqui, não sinto nada daquilo que senti quando estava entre os Azande".

Durante a minha vida fui tão dura que eu participei daquilo tudo e tal, mas nunca realmente me abalei. Já levei meus irmãos, um deles, Luiz, meu irmão mais novo, entrou em transe no terreiro. E a minha irmã mais nova, a Jeanne, que foi comigo lá no Tenda Caboclo, em Serra Negra, chegou uma certa hora e ela falou: -"Eu vou embora, vou embora, vou embora". Era no meio da noite e ela falou: -Não, eu pego um táxi aqui. Eu vou-me embora”. No dia seguinte, eu liguei para ela e perguntei: - “o que te deu? O que houve?” Ela: —“Eu fiquei com muito medo de você. Você estava fazendo tudo tão igual a eles que eu achei que você ia virar mãe de santo. Você estava totalmente à vontade". E eu acho que o Victor Turner viu e sentiu os Ndembu.

É uma coisa interessante que eu, agora na velhice, perceba que vi coisas em momentos muito cruciais da vida. Quando o Domingos nasceu, a minha babá, que me criou, e dizia ser filha de índio, fez um batizado dele à lua, sabe? Ofereceu o Domingos, antes de ele ser batizado no catolicismo, aos sete anos. Eu tinha uma ligação muito grande com essa babá, a Isaura. E eu fiquei grávida, tive o filho. E a filha dela, também teve filho, na mesma época. Depois que o Domingos nasceu, de repente eu me vi sem Isaura, porque Isaura me acompanhou a vida inteira, desde que eu nasci. E um dia, eu, naquelas noites sem dormir direito... porque quando você tem filho fica sem dormir muito, não é?

M.L.V.C.C. Eu sentia cansaço nos ossos. Nunca mais senti isso na minha vida... Y.M. Você ficava assim, pairando, parecia até que levitando de tanto cansaço. E Domingos chorou muito nos primeiros meses. E um dia eu vi uma preta-velha na varanda. Eu olhei e achei que era Isaura, fui falar e não era. Era uma visão. Depois quando eu estava lá nesse terreiro da Dona Conceição, eu era muito explorada, eu tinha um fusquinha e ia para tudo quanto é canto com aquele fusquinha, com milhares de pessoas dentro. Fomos fazer um trabalho em uma 
mata e eu, branca desse jeito, entrei dentro daquela mata ali de Furnas, nem sei se é Mesquita, sei lá mais onde é! Começou aquele monte de mosquito e eu comecei a ficar toda empolada. Fiquei com medo de morrer, de ter um edema de glote, sabe? Mas fiquei lá. E depois fiquei com medo porque vinha uma tempestade. Eles começaram a subir e iam lá na cascata. E eu cheguei na cascata, toda mordida e todo mundo rindo de mim. Porque você fica naquela posição de total estranheza. E eu olhei e vi um homem muito bonito, em cima de uma pedra. Caboclo mesmo, com aquela cor de caboclo, uma sunga assim pequena. E o cara mergulha no poço, era um poço pequeno. E eu fico olhando... e o cara não aparece! E eu tocava as pessoas: "Poxa, ele entrou ali. Cadê ele? Ele morreu!" E todo mundo às gargalhadas: "Ela viu o caboclo! Ela viu o caboclo!" Então, essas coisas aconteceram na minha vida, e eu sempre falei brincando. Porque, como ocorreu com o Evans-Pritchard, eu não sei explicar isso.

M.L.V.C.C. Viu o fogo, não é? Viu a feitiçaria zande.

Y.M. Viu a feitiçaria zande. Mas quando eu fiquei doente e fui me operar, quando eu saí da anestesia, saí passando muito, muito mal. Com muita falta de ar, e achei que eu ia morrer ali, mas também não tive medo de morrer não. Uma coisa estranha. Até quis, porque estava tão ruim... Aí eu via milhares de Obaluaê. Eu não estava dormindo. Eu via rodando, rodopiando com aquela roupa de palha, com a cabeça como se fossem Obaluaês sendo feitos. Que fica aquela carequinha assim e a roupa de palha. Eu não penso nisso nunca e já não estudo mais isso há séculos. Mas tinha milhares e milhares. E eu falava para o meu filho com medo: -"Domingos, estou vendo muitos Obaluaês". Aí o Domingos foi lá no computador, ele estava comigo essa noite no hospital, e disse: -"Fica tranquila, mamãe, porque Obaluaê [eu não podia nem explicar, não estava com força] é muito bom, ele não está fazendo a sua passagem, ele quer que você fique aqui". Acho que o Roberto DaMatta tem toda razão, nossa sociedade é muito mais metonímica, neste sentido de as coisas irem se juntando. Por isso o Lévi-Strauss fala que o ritual é balaio de gato, porque não é cartesiano como a França, como os índios estudados por ele.

M.L.V.C.C. Fala um pouco da nova edição do livro em 200 I. Como foi essa retomada?

Y.M. As duas edições primeiras foram iguais. Porque também foram em curto intervalo: I975 e I977. Depois eu passei muitos anos sem retomar o Guerra de Orixá. Quando eu editei a segunda vez, o Jorge Zahar não queria que eu assinasse Yvonne Maggie. Ele era muito amigo do Gilberto e ficou muito chocado com a nossa separação. Éramos muito amigos, e ele me disse quando publiquei: "Yvonne, esse livro vai mudar a sua vida". Na época que ele disse isso, eu fiquei com muita culpa, tudo o que aconteceu foi um espanto. Eu deveria ser como as minhas irmãs, mães de muitos filhos. Sabe? As mulheres da minha geração 
entraram na vida acadêmica de uma forma muito consciente. Eu lembro que, conversando com a Eulália Lobo, que é a pessoa para mim que mais representou uma mulher intelectual, historiadora, que tinha consciência dos limites da mulher na vida acadêmica; ela foi da primeira turma de história da FNFi [Faculdade Nacional de Filosofia], em i939. Ela contou como ela entrou na faculdade. Isso não era suposto! Eu sou mais nova, mas mesmo assim, em I965, tinha muito mais meninos do que meninas no curso de Ciências Sociais. Eu fazia um esforço, mas sem essa consciência que os homens da minha geração tinham. “Eu vou ser isso!" Hoje é tudo mais unissex. Homens e mulheres são mais próximos. Na minha geração eram muito apartados. Minhas amigas tiveram crises enormes. Quando se separavam e, muitas vezes, eram da mesma profissão do marido, iam fazer outra coisa... Sabe? E eu continuei. Um espanto para mim. O Richard Price, quando leu a nova versão do meu livro, disse: "É uma joia de uma etnografia clássica”. No posfácio do livro, eu procurei atualizar o debate, depois tanta gente escreveu sobre umbanda, sobre terreiro. Talvez eu devesse ter falado mais sobre a minha trajetória. Mas eu quero dizer o seguinte: tudo isso é um Brasil que não existe mais.

M.L.V.C.C. Quando você escreveu, a umbanda era um tema muito central. Havia uma simbolização de Brasil também na umbanda... A umbanda revelava também um momento brasileiro, não é?

Y.M. A umbanda era uma coisa central na vida urbana. O Peter falou sobre isso no artigo "Duas respostas à aflição". ${ }^{\text {to }}$ Não se compara com o Brasil de hoje de maneira alguma. Porque a cidade mudou. O país mudou. Ficamos muito mais modernos. Muito mais ricos. Nesses anos todos, eu vi transformações no Brasil inacreditáveis. Simbolicamente. Religiosamente. Educacionalmente. Acho que eu vivi essa grande transformação do Brasil de um país tradicional, carismático, do favor, para um país muito mais burocrático, tentando ter regras mais explícitas de alguma forma e buscando a democracia, apesar dos percalços que temos encontrado.

Entrevista concedida no dia ro de maio de 2013, na casa de Yvonne Maggie, no Leblon, Rio de Janeiro. 
Maria Laura Viveiros de Castro Cavalcanti é doutora em Antropologia pelo Museu Nacional/UFRJ, e professora do Departamento de Antropologia Cultural e do Programa de Pós-Graduação em Sociologia e Antropologia do Instituto de Filosofia e Ciências Sociais da Universidade Federal do Rio de Janeiro (IFCS-UFRJ). É autora de O Mundo Invisível; cosmologia, sistema ritual e noção da pessoa no espiritismo (I 983), O rito e o tempo: ensaios sobre o carnaval (I 999), Carnaval carioca: dos bastidores ao desfile (2006). Reconhecimentos: Antropologia, folclore e cultura popular (20I2), seu livro mais recente, foi premiado com Menção Honrosa no concurso ANPOCS de Obras Científicas, de 2013.

Valter Sinder é doutor em Letras pela Pontifícia Universidade Católica do Rio de Janeiro (PUC-Rio). É professor no Departamento de Sociologia e Política desta mesma Universidade e do Departamento de Ciências Sociais da Universidade do Estado do Rio de Janeiro (UERJ). É autor de Configurações da narrativa: verdade, literatura e etnografia (2002).

Gisele Carino Lage é mestre em Sociologia (com concentração em Antropologia) pelo Programa de Pós-graduação em Sociologia e Antropologia (PPGSA) do Instituto de Filosofia e Ciências Sociais da Universidade Federal do Rio de Janeiro (IFCS-UFRJ), com a dissertação Uma luz no fim do túnel: um estudo de caso em uma escola diferente (2010). Atualmente cursa o Doutoramento em Antropologia Cultural no mesmo Programa. É também pesquisadora do Núcleo de Antropologia na Escola (NaEscola) no IFCS. Desde 20r2, é professora de Sociologia no Instituto Federal de Educação, Ciência e Tecnologia (IFRJ). 


\section{NOTAS}

I A revisão e a edição das duas entrevistas foi realizada por Maria Laura Viveiros de Castro Cavalcanti.

2 Os textos referidos são: "Entrevista com Roberto DaMatta", em Desigualdade\&Diversidade. Revista de Ciências Sociais da PUC-Rio, 8, jan/jul, 20I I, p. I I-50; "Conversa com RobertoDaMatta”, em Conferências e diálogos: saberes e práticas antropológicas, $25^{\text {a }}$ Reunião Brasileira de Antropologia, Goiânia, 2006. ABA, 2007, p. 259-28I; "Apresentação liminar à obra e à graça de Victor Turner e à sua antropologia da ambiguidade", em Floresta de símbolos. Aspectos do ritual Ndembu (Niterói: EdUFF, 2005, p. I5-28).

3 DaMatta refere-se ao texto "Between and betwix: o período liminar nos 'ritos de passagem'", que seria apresentado por Victor Turner, em I964, no Encontro Anual da American Ethnological Association e viria a compor o IV capítulo do livro Floresta de símbolos, publicado em português em 2005 pela EDUFF.

4 Roberto DaMatta foi para Harvard com bolsa da Fulbright. Voltaria ainda para um segundo período de estudos entre I967-I970, com apoio do CNPq e da Fundação Ford, tendo obtido o Ph.D em I97 I com uma tese sobre a estrutura social dos Apinajés, publicada como 0 mundo dividido, em I976, pela Editora Vozes.

5 Victor Witter Turner nasceu em I920, na Escócia, e faleceu em I983, nos Estados Unidos. Foi pesquisador do Instituto Rhodes Livingstone, na então Rodésia do Norte, na África, entre I950-I954. Entre I954-I963 associou-se como conferencista à Universidade de Manchester, na Inglaterra. Nos Estados Unidos, foi professor na Universidade de Cornell, Ithaca, Nova York, entre I963-I968; na Universidade de Chicago, em Chicago, Illinois, entre I968-I977; na Universidade de Virginia, Charlottesville, Virginia, entre I977-I980. Lecionou também na Universidade de Princeton, em Princeton, New Jersey, entre I975-1977.

6 Roberto DaMatta lecionou na Universidade de Notre Dame, em South Bend, Indiana, onde ocupou a Cátedra de Antropologia entre 1987 e 2004.

7 DaMatta refere-se a "Carnaval in Rio: Dionysian drama in an industrializing society", que foi incluído no livro The anthropology of performance (Nova York: PAJ Publications, 
I987, p. I23-I38), uma coletânea póstuma de artigos de Victor Turner organizada por Richard Schechner. Embora Turner cite várias vezes o trabalho de Roberto DaMatta, que emerge nesse texto também como o guia da incursão do casal Turner pelo Carnaval do Rio de Janeiro, em I980, por algum lapso editorial esse artigo não traz a bibliografia citada por seu autor.

80 artigo foi publicado em The anthropology of performance. Nova York: PAJ Publications, I987, p. 33-7I. Uma versão diferente e apenas datilografada do diálogo com a pesquisa de Maggie intitula-se "Conflict in Social Anthropology and psychoanalytical theory: Umbanda in Rio de Janeiro". Traz a dedicatória: "With admiration, for Yvonne, from Vic. December, I980".

9 Yvonne refere-se a "Drama social: notas sobre um tema de Victor Turner", de Maria Laura Viveiros de Castro Cavalcanti, publicado na revista Cadernos de Campo, I6, 2007, p. I27I37.

Io Trata-se do artigo "Umbanda e pentecostalismo: Duas respostas à aflição", de Peter Fry, publicado originalmente na revista Debate e Crítica, 6, I975, p. 25-39. 


\section{VICTOR TURNER E A ANTROPOLOGIA NO BRASIL. DUAS VISÕES. ENTREVISTAS COM ROBERTO DAMATTA E YVONNE MAGGIE}

\begin{abstract}
Resumo
As entrevistas com Roberto DaMatta e Yvonne Maggie iluminam a fecunda interlocução da antropologia brasileira com a obra de Victor Turner. A relevância dos rituais na vida social e a inclusão das sociedades ocidentais na investigação antropológica foram centrais para Roberto DaMatta cuja obra renovou as ciências sociais brasileiras. O conceito de drama social, por sua vez, inspirou Yvonne Maggie, cujo trabalho abriu novos caminhos na antropologia urbana e da religião. Nossos entrevistados falam de uma antropologia vivida tanto no campo das pesquisas como no convívio intelectual feito de muitas leituras e estudos compartilhados com professores e colegas. Falam dos insights que impulsionaram ricos processos de pesquisa; trazem aspectos pouco conhecidos de um momento marcante da antropologia feita no Brasil.
\end{abstract}

\section{VICTOR TURNER AND ANTHROPOLOGY IN BRAZIL. TWO PERSPECTIVES. INTERVIEWS WITH ROBERTO DAMATTA AND YVONNE MAGGIE} prominent role in social processes and the inclusion of Western societies in anthropological research deeply influenced DaMatta's own work, which renewed Brazilian social sciences as a whole. The concept of social drama, in turn, inspired Maggie's research, which broke new grounds in the anthropology of religion and urban anthropology. The interviews tell us about a lively anthropology based not only in field research, but also in many intellectual interchanges shared with teachers and colleagues. They tell us about the insights that drove rich research processes as well as little-known but remarkable aspects of a highly innovative moment of anthropology in Brazil.
Palavras-chave

Victor Turner; Antropologia no Brasil; Ritual; Análise simbólica; Drama social.
Keywords

Victor Turner; Anthropology in Brazil; Ritual; Symbolic analysis; Social drama. 